\title{
Metody zbierania i suszenia roślin oraz przechowywania zbiorów zielnikowych w polskiej literaturze w latach 1785-1939
}

\author{
KRZYSZTOF KAPAŁA
}

\begin{abstract}
KAPAŁA, K. 2020. Methods of collecting and drying plants and storing herbarium collections in the Polish literature in 1785-1939. Fragmenta Floristica et Geobotanica Polonica 27(2): 615-638. Kraków. e-ISSN 2449-8890, ISSN 1640-629X.

AвSTRACT: The paper presents changes in the methodology of collecting, drying and storing plants over a period of more than 150 years. Methodological works were published during the times of the Polish-Lithuanian Commonwealth, the Partitions of Poland between Russia, Prussia and Austria, during World War I, and in the interwar period. Plants were collected for herbaria by people of different educational backgrounds, not always in biology. They were usually teachers, school pupils, students and priests, who by collecting plants according to different protocols contributed to knowledge of the native flora. The presented publications also contributed significantly to knowledge of the country's flora.

Initially, manuals about collecting, preserving and storing botanical specimen were prepared for particular scientific aims. Later, with the increase in the number of publications promoting plant collecting, herbaria were gathered by numerous hobbyists. Plants frequently were gathered to meet the needs of collectors and to provide educational resources for training amateur botanists. Originally, from the early 19th to early 20th centuries, readers were encouraged to collect plants for herbaria and for exchange. In the 1920s, however, when the disappearance of rare plant species was noticed, critical opinions appeared, calling for restriction or even ceasing of herbarium preparation.
\end{abstract}

KEY WORDS: herbaria, plant collecting, plant drying

K. Kapała, Uniwersytet Jagielloński, Wydział Biologii, Ogród Botaniczny, ul. Kopernika 27, 31-501 Kraków,Polska; e-mail: krzysztof.kapala@uj.edu.pl

Herbarium praestat omni Icone, necessarium omni Botanico Zielnik przewyższa wszelkie ryciny, niezbędny każdemu botanikowi

K. Linneusz, Philosophia Botanica 1751

\section{WSTĘP}

Zasady tworzenia zielników oraz związane z tym sposoby zbioru roślin i ich przygotowywania do przechowywania zmieniały się na przestrzeni czasu. Informacje na ten temat w okresie od końca XVIII w. do pierwszej połowy XX w. były publikowane jako opracowania oraz drobne informacje rozrzucone w krajowej literaturze, dotyczące metod tworzenia, gromadzenia i przechowywania zbiorów zielnikowych. Większość z tych prac stanowi 
obecnie dzieła trudno dostępne, rzadko spotykane w bibliotekach, nieznane szerszemu gronu odbiorców.

Inspiracją do poszukiwań informacji dotyczących tytułowego zagadnienia była książka Zielnik i zielnikoznawstwo (DROBNIK 2007) oraz własne zbiory literatury dotyczące tego fascynującego problemu botaniki. Wbrew opinii autora wymienionej publikacji, w polskiej literaturze przyrodniczej odnajdujemy liczne prace związane z opisem zbioru, suszenia oraz przechowywania kolekcji roślin. Pierwsze polskie instrukcje dotyczące wykonywania zielników pochodzą już z XVIII w., a w późniejszym czasie (druga połowa XIX w. i początek $\mathrm{XX}$ w.) stały się dość popularne wśród licznego grona naszych przyrodników.

Niektóre publikacje mają charakter przyczynkowy i uzupełniają wiadomości publikowane w popularnych czasopismach (Dziennik Wileński, Wszechświat i Kosmos) lub jako rozdziały podręczników. Ciekawą i mało znaną obecnie grupę stanowią dzieła, które w formie odrębnych wydawnictw, często kieszonkowego formatu, obejmowały zbiór praktycznych informacji związanych z gromadzeniem zbiorów przyrodniczych, w tym ze zbiorem i urządzaniem zielnika czyli herboryzacją. Część publikacji zawiera ryciny przedstawiające najważniejsze narzędzia potrzebne do zbioru, transportu oraz procesu suszenia okazów (Ryc. 1). Rośliny były zbierane do zielników przez osoby o różnym wykształceniu, nie zawsze przyrodniczym. Byli to zazwyczaj nauczyciele, uczniowie szkół, studenci i duchowni, którzy poprzez zbieranie roślin według określonego schematu, przyczyniali się do poznania rodzimej flory. Wartość tego typu zespołowych badań podkreślali liczni autorzy na przestrzeni ostatnich 200 lat. Odezwy związane z gromadzeniem i wymianą zbiorów zasuszonych roślin były początkowo formułowane przez pojedynczych naukowców, w późniejszym czasie to zadanie przejęły liczne towarzystwa naukowe (KöHLER 2015).
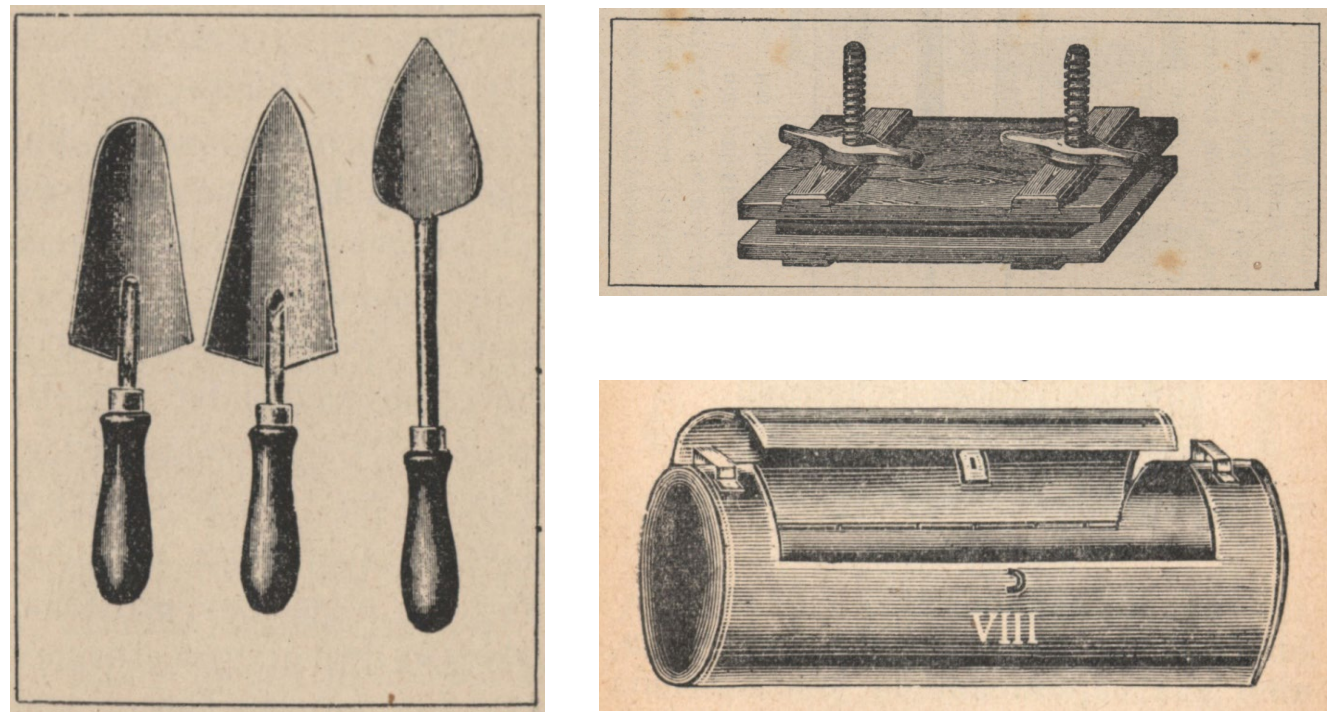

Ryc. 1. Narzędzia potrzebne w czasie botanizowania: różne typy łopatek, prasa oraz obecnie zapomniana botanizerka (ARctówna 1905; Cienciala 1924)

Fig. 1. Tools for plant collecting: a variety of small spades, a press and (no longer used) botanical box (vasculum) (Arctówna 1905; Cienciąa 1924) 
Przykładem botanika-amatora, zamiłowanego w zbieraniu roślin, może być Eliza Orzeszkowa (1841-1910), która pisała: „(...) zajmowałam się bardzo żywo i gorliwie światem roślin, botanizowaniem, ze specjalnym celem poznawania stosunku ludu naszego do otaczającej go natury. Zbierałam rośliny, dopytywałam się wieśniaków (szlachty zagrodowej i chłopów) jak je nazywają, do czego używają, jakie do nich wiążą podania etc. (...), poznałam pewną wiejską lekarkę, nie czarownicę wcale, ale lekarkę, (...) nauczyła mnie mnóstwa rzeczy bardzo ciekawych. (...) Zebrałam sobie tym sposobem zielnik z dwustu kilkudziesięciu okazów złożony, z odpowiednim szeregiem nazw ludowych i różnych, szczególniej leczniczych, znaczeń. Zajmowało mnie to i pochłaniało ogromnie” (KIELAK 2006).

Rośliny do zielników pozyskiwane były za pomocą różnych narzędzi, suszone, opisywane i przechowywane. $\mathrm{Z}$ czasem metody te były modyfikowane i uzupełniane w miarę postępującej na ten temat wiedzy.

Celem niniejszej pracy było chronologiczne przedstawienie zmian metodycznych związanych ze zbiorem roślin, ich suszeniem oraz przechowywaniem, jakie były prezentowane w polskiej literaturze przyrodniczej w latach 1785-1939.

\section{PubliKaCJE NA TEMAT SPOSOBÓw TWORZENIA ZIELNIKÓw - XVIII i XIX w.}

Ksiądz Krzysztof Kluk (1739-1796), człowiek o wszechstronnych zainteresowaniach, zasłynął przede wszystkim jako botanik. Opublikował liczne prace, które ówcześnie były przełomowe dla polskich nauk przyrodniczych i rolniczych. I to właśnie Klukowi zawdzięczamy pierwsze w krajowej literaturze botanicznej wzmianki dotyczące instrukcji zbioru, suszenia i układania roślin. Autor na kilku ostatnich stronach swojego podręcznika Botanika dla szkót narodowych Pierwszy raz wydana (Ryc. 2), opublikowanego w Warszawie w 1785 r. (KLUK 1785) podkreśla korzyści płynące ze zbierania i układania zielników dla młodzieży, dzięki którym młody adept botaniki łatwiej sobie przypomni jak roślina wygląda, jakie są jej części i do której należy gromady. Zwraca również uwagę, że choć kosztowne kopersztychy (miedzioryty) są dokładne i bardzo dobrze odwzorowują roślinę, nigdy nie okażą się tak doskonałe, jak dobrze ułożona i zasuszona roślina. Omawia również sposoby zbioru roślin: „Idąc na zbieranie roślin czyli herboryzację, trzeba mieć ze sobą koszyk, do niego wkładać rośliny i mchem świeżym prześcielać, aby nie powiędły, a jeśli by to już nastąpiło trzeba w wodę wstawić aż odwiędną". Opisuje również szczegółowo sposoby postępowania z zebraną rośliną, częstotliwość przekładania roślin do suchej bibuły: „co dwanaście godzin, rano i wieczór przez kilka dni potem już tylko co trzeci dzień do zaschnięcia”. Podaje również kilka praktycznych rad dotyczących zachowania koloru roślin, kształtu oraz części roślin, które powinny znaleźć się w zielniku. „Są także rośliny, osobliwe ich kwiaty, farby delikatniejszej np. granatowej lub czerwonej: te ususzone, mimo wszelakiego starania, przecież kolor swój tracą. Takowe kwiaty skoro się przyniosą; trzeba je zaraz przez bibułę gorącym żelazkiem przeprasować, póki zupełnie nie uschną, wystrzegając się najbardziej przyciskania zbytnie kwiatu: jeżeli i to nie pomoże, doda się kolor dobraną farbą". Dalszy ciąg opisu dotyczy sposobu przechowywania roślin: luźno na papierze lub przyklejane na arkusze za pomocą kleju rybiego, do którego dodawano odrobinę olejku goździkowego, 


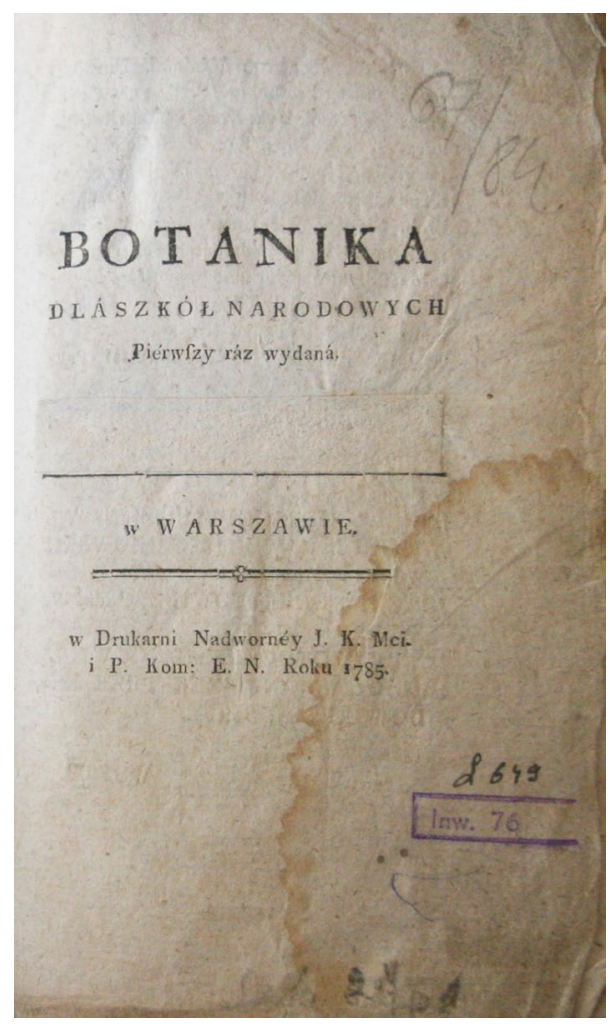

Ryc. 2. Strona tytułowa podręcznika botaniki „Botanika dla szkół narodowych” Krzysztofa Kluka (Biblioteka Instytutu Botaniki Uniwersytetu Jagiellońskiego)

Fig. 2. Title page of Botany for national schools by Krzysztof Kluk (Library of the Institute of Botany, Jagiellonian University) odstraszającego owady. Autor podaje również informacje jakie powinny się znaleźć na arkuszu z rośliną, a więc: nazwa, określenie „częśsi wzrostu”, „części owocowania”, miejsce na którym rosła, datę zbioru, czy jest jednoroczna czy dwuletnia oraz w jaki sposób może być wykorzystana. Tak przygotowane arkusze powinny być posegregowane na poszczególne gromady.

Rozszerzone informacje na temat pozyskiwania roślin i wykonywania zielników przynosi anonimowa Instrukcya do uktadania zapisów w przedmiocie botaniki (ANONIM 1816) zamieszczona na łamach Dziennika Wileńskiego. Dokument, jak pisze Wanda Grębecka, ,sygnowany był przez ministra", jednak pomimo usilnych poszukiwań autorki nie udało się ustalić, kto był jego twórcą (GRĘBECKA 1993). Zapisy w przedmiocie botaniki krótko opisują przygotowanie papieru oraz roślin: „Potrzeba wybierać najdoskonalsze i najlepsze egzemplarze zupełnie rozkwitłe, wyrywać je z korzeniami i ze wszystkimi liściami”, proces suszenia „,rośliny które żółkną lub czernieją, powinny być suszone na słońcu i w otwartem powietrzu, tyle tylko aby ich świeżość jeszcze została i aby można było wyprostować liście", a także ich późniejsze przechowywanie.

Nieco później wiadomości dotyczące sposobu zbierania, suszenia i przechowywania zbiorów botanicznych opublikował Willibald Besser (1784-1842), zasłużony dyrektor Ogrodu Botanicznego w Krzemieńcu oraz profesor Liceum Krzemienieckiego. Besser od młodości zbierał rośliny oraz sporządzał zielniki, sam odziedziczył zbiory po Burkhardzie Suibercie Schiverecku (1742-1806), a także zgromadził liczne zbiory w drodze wymiany z botanikami-amatorami. Pisał: „,bez zielników nikt dobrej flory nie napisze”. Na łamach popularnego wówczas Dziennika Wileńskiego ogłasza drobiazgowy poradnik Przepisy do układania zielników (BESSER 1826), który ukazał się również jako osobna odbitka z własną kartą tytułową - wydana drukiem przez Józefa Zawadzkiego, brak daty wydania (Ryc. 3). Zamieścił w nim wszystkie niezbędne wiadomości, które umożliwiały nauczycielom sporządzanie zbiorów o walorze naukowym, możliwych później do wykorzystania przez badaczy flory (GRĘBECKA 1988). Podaje też jakie informacje należy zanotować w terenie i umieścić na etykiecie dołączonej do każdego egzemplarza. Były to dane niezbędne do prawidłowego oznaczenia rośliny i dotyczyły jej rozmiarów, pokroju, szczegółów morfologicznych, fenologii, siedliska oraz stanowiska, a także terminu zbioru. Co ciekawe, Besser zalecał 
również zbiór roślin uprawianych i aklimatyzowanych pisząc: „umieszczenie takich roślin do flory daje mniej więcej wyobrażenie o klimacie i przemyśle narodowym, o postępie oświecenia i uprawy, a uczniom botaniki służy do ćwiczenia się w zastosowaniu wyrazów technicznych do wiadomszych przykładów". Jako pierwszy zwracał uwagę na istotną rolę nauczycieli szkół powiatowych i gimnazjów, amatorów ogrodów i uczniów, mieszkających w różnych częściach kraju jako tych, dzięki którym poprzez zbieranie materiału zielnikowego możliwe jest dokładne zbadanie flory ojczystej. Współpraca z nauczycielami dawała mu możliwość poszerzenia zasięgu gromadzonych kolekcji roślinnych o miejsca znacznie oddalone od Krzemieńca (GRĘBECKA 1992). Relacje między uczonym, prowadzącym rozległe badania, a młodymi pracownikami w terenie charakteryzował następująco: „Zbieranie roślin bardziej jest dziełem dobrych wprawionych oczu i nóg niż głowy. Idzie więc naprzód o to abym miał w tym jak najwięcej pomocników. Zachęcam jak mogę amatorów ogrodów i uczniów do zbierania roślin krajowych, popieram ich i radzę wszelkimi sposobami. Liczny zbiór roślin krajowych, pomiędzy któremi wiele jest nowych i nieopisanych, jest tego skutkiem" (GRĘBECKA 1992). Autor omówił niezwykle szczegółowo, w formie instrukcji, poszczególne etapy związane ze zbiorem roślin i tworzeniem zielnika. Wskazuje na konieczność opisu fizjograficznego miejsca zbioru roślin, bliskości pasm górskich, rzek, jezior, rodzaju gleby - ,jakie grunta czy gliniaste, żwirowate, kamieniste, piaski, czarnoziem" - na jakim dana roślina występuje. Zwraca uwagę, aby zbierać nie tylko rośliny dziko występujące na danym terenie, ale i gatunki uprawne: „kuchenne, farbiarskie i lekarskie”, co „daje mniej więcej wyobrażenie o klimacie i przemyśle narodowym, postępie oświecenia i uprawy”. Zaleca wybór rośliny nieprzewyższającej dwa razy długość arkusza. Jeśli rośliny są znacznej wysokości, należy zebrać część ze spodu z korzeniem, ze środka oraz wierzchołek. Z drzew suszy się gałązki z kwiatami i ,nasiennikami”'(owocostanami, nasionami), a osobno ulistnione pędy, ponieważ, jak wyjaśnia autor, ich liście często różnią się formą od tych przykwiatowych. W części dotyczącej suszenia roślin opisuje tradycyjny sposób przekładania roślin w bibuły, a następnie zaleca przyłożenie deszczułką i ciężkim kamieniem lub cegłą. Zwraca uwagę, aby co najmniej raz na dobę zmieniać bibuły, w przeciwnym razie rośliny zaczną czernieć i pleśnieć. W przypadku roślin o grubych łodygach, korzeniach i cebulach

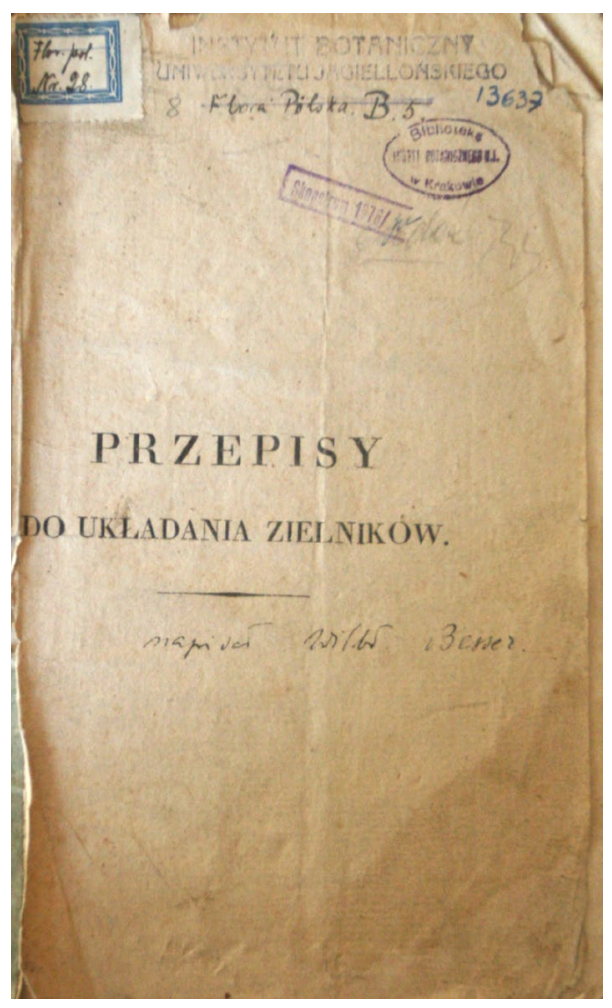

Ryc. 3. Karta tytułowa „Przepisów do układania zielników” BESSERA (1826) - zbiory Biblioteki Instytutu Botaniki UJ

Fig. 3. Title page of Guidelines for arranging herbaria by BESSER (1826) - from the collections of the Library of the Institute of Botany, Jagiellonian University 
poleca ich przecięcie wzdłuż, a dla roślin mięsistych o dużej ilości wody moczenie we wrzącej wodzie, a następnie tradycyjne dosuszanie w bibule. W przypadku storczyków i innych roślin, które w czasie suszenia znacznie tracą swój wygląd i stają się do „ściślejszego rozpoznania i zdeterminowania niezdatnymi, należy oprócz ułożenia i zasuszenia" tradycyjnymi metodami, zastosować konserwację na mokro z użyciem: spirytusu, wódki, syropu cukrowego albo roztworu solnego. W trakcie suszenia, dla zachowania koloru kwiatów, zaleca używać do układania bibuły zamoczonej w lekkim roztworze ałunowym i potem doskonale wysuszonej lub też soli kuchennej (co jednak, jak autor zaraz dodaje, jest metodą mało skuteczną).

Besser jako pierwszy wspomina również o suszeniu grzybów, co jest trudne tradycyjnym sposobem. Jako skuteczną metodę opisuje obsypanie owocników czystym rozgrzanym piaskiem i utrzymanie w miejscu ciepłym dopóki nie wyschną. Jako uzupełnienie poleca wykonać modele $\mathrm{z}$ wosku, a także dodać rysunki ogólnego wyglądu oraz przekroje poprzeczne i podłużne, aby przedstawić ich wewnętrzny wygląd. Niektóre z gatunków można zakonserwować w „mocnym wyskoku” (alkoholu), jednak i przy tym rodzaju konserwacji tracą one kolor, który często jest ważną cechą diagnostyczną.

W przypadku rzadszych gatunków należy, jak pisze, zbierać po 2-3 okazy dla możliwości porównania oraz wszystkie „trafiające się odmiany”. Zaleca zbierać nie tylko okazy kwitnące, ale i owocujące (zwłaszcza turzyce, róże, krzyżowe oraz baldaszkowate) i układać kwitnące egzemplarze z owocującymi razem w bibułach, dzięki czemu znacznie łatwiej je później zidentyfikować. W celu przechowywania okazów należy ułożyć je starannie w bibule, tak aby żadna ich część nie wystawała poza arkusze, a następnie złożyć po 50 lub 100 arkuszy w jedno miejsce. Paczka taka (fascykuł) powinna zostać owinięta szczelnie papierem, aby uniemożliwić dostęp owadów do zielnika, następnie należy ją obłożyć z obu stron tekturą i obwiązać mocno szpagatem. Tak ułożone zielniki należy przechowywać w suchym miejscu, gdyż najgorszym wrogiem zielnika jest wilgoć. W części dotyczącej szkodników zielników autor wymienia gatunki chrząszczy: skórnik chlebowy (Anobium paniceum), kołatek potajemny (Ptinus fur) oraz jeden gatunek motyla: ćma dziobowata (Herminia rostralis) i podkreśla, że częste przeglądanie i staranne obwiązywanie najlepiej ochroni zielniki od plagi szkodników. Besser bardzo szczegółowo wymienia wszystkie istotne informacje, które powinny znaleźć się na kartach dołączonych do okazów. Zwraca uwagę, aby „oznaczyć rzadkość lub obfitość rośliny” oraz podać kto ją po raz pierwszy odkrył lub zasuszył. Ponadto namawia do zapisywania nazw ludowych oraz możliwości wykorzystania roślin „na pokarm, lekarstwo, do farbowania”. W końcowej części podkreśla, iż rośliny powinny być ponumerowane, a do zielnika powinien być dołączony podwójny spis - pierwszy, który zostaje u tworzącego zielnik, a drugi - przesyłany wraz z zielnikiem.

W celu wysyłki rośliny, zasuszone według wcześniej opisanego sposobu, układa się gęsto, karteczki z napisami nawlekając od dolnego końca na roślinę. Tak opisane przekłada się półarkuszem (jeśli są delikatniejsze) lub całym arkuszem (w przypadku roślin o grubych łodygach) w stosiki wysokie na 4 do 5 cali, następnie uciska się w prasie lub przygniata ciężarkiem, aby się dobrze uleżały i związuje cienkim sznurkiem. Przygotowane paczki po $2,3,4$, związane razem okłada się z dwóch stron tekturą, owija bibułą i obszywa grubym płótnem lub ceratą. Jeśli grubość paczki przekracza 12 cali, powinno się podzielić ją 
na mniejsze przesyłki lub spakować do drewnianej skrzynki, którą obszywa się płótnem. Besser zwraca uwagę na cztery podstawowe błędy, których należy unikać podczas pakowania roślin, a mianowicie: (1) by grubsze łodygi nigdy się nie krzyżowały, (2) szersze liście nie leżały na grubszej łodydze ani pod nią, (3) by paczka była jak najlepiej związana oraz (4) solidnie zabezpieczona bibułą lub zwykłym papierem, aby w czasie deszczu nie uległa przemoczeniu. Omawiając również przygotowanie i urządzenie ,zielników publicznych”, zaleca mocowanie roślin za pomocą 2-3 małych pasków papierowych na niezbyt twardych arkuszach. Karteczkę z nazwą i wcześniej wymienionymi danymi przykleja się do prawego dolnego rogu, a w dolnym lewym rogu należy zapisać nazwę rodzaju, rzędu, rodziny lub klasy do których należą rośliny i według jakiego systemu zostały uszeregowane. Paczki roślin, na 3 lub 4 cale grube, należy starannie owinąć papierem, na grzbiecie zaznaczając z jakiej są rodziny, rzędu, klasy, wyszczególniając rodzaje.

Około 40 lat później została opublikowana przez Ignacego Rafała Czerwiakowskiego (1808-1882) Instrukcja dla członków sekcji botanicznej Komisji fizjograficznej (CzERWIAKOWSKI 1867). Autor w nowo powstałym naukowym wydawnictwie Komisji Fizjograficznej zamieścił wytyczne, zalecenia i wskazówki dotyczące zbioru, suszenia, pakowania oraz przesyłania zasuszonych roślin. W instrukcji zaznacza, iż zawodowi członkowie sekcji moga przesyłać dla ułatwienia tylko spis roślin z uwagami. W przypadku ,niemożności dokonania oznaczenia" przez osoby nie będące zawodowo związane z botaniką, zbierający proszeni są o przesyłanie okazów zielnikowych według załączonej instrukcji. Zalecenie zawiera uwagę, iż roślina musi być kompletna „od korzenia aż do owocu, z wszystkimi częściami”, zbierana zarówno w fazie kwitnienia, jak i owocowania. Według autora najlepiej zbierać rośliny średnich rozmiarów, suszyć je w naturalnym położeniu jak najbardziej zbliżonym do naturalnego, ,bez żadnych naginań lub wyprostowań sztucznych, z lekka i gładko porozkładanemi liśćmi, oraz jednym przynajmniej doskonałym kwiatem należycie rozpostartym”. Zwraca uwagę na podstawowe informacje jakie muszą się znaleźć przy opisanym okazie. Prosi o zamieszczanie ,na dołączonej kartce łacińskich, polskich i ruskich” nazw oraz, jeśli istnieje, podanie nazwy ludowej. Podnosi celowość określenia częstości występowania i podania informacji „czy występuje w pojedynczych okazach” albo też gromadnie.

Kolejną wzmiankę w polskiej literaturze botanicznej drugiej połowy XIX w., dotyczącą sporządzania zielników odnajdujemy w małej książce Aleksandra Ślendzińskiego (1848-1881), poświęconej zagadnieniom muzealnictwa przyrodniczego, pt. Poradnik dla urzqdzajacych zbiory przyrodnicze (ŚLENDZIŃSKI 1874). Praca ta została wydana w Krakowie w 1874 r., a więc w czasie, kiedy autor pracował jako asystent profesora Ignacego Rafała Czerwiakowskiego w Ogrodzie Botanicznym Uniwersytetu Jagiellońskiego. Książka, oprócz części poświęconej zbieraniu roślin, zawiera opisy preparowania zwierząt, owadów, robaków, a także część, w której jest mowa o przysposabianiu minerałów do zbiorów. Rozdział dotyczący roślin obejmuje 17 stron (od 80 do 96). W początkowym fragmencie pracy autor wylicza narzędzia niezbędne podczas zbierania roślin czyli herboryzacji: nóż ogrodniczy, żelazna łopatka, nurek druciany - ,do wyciągania i przyciągania roślin głęboko w wodzie i daleko od brzegu będących, oraz laskę długą z krukiem” (laska z haczykiem), dłuto i młotek (do oddzielania porostów rosnących na kamieniach) oraz „,blaszane pudełko lub tekturę z arkuszami bibuły". 
W dalszej części pracy Ślendziński powtarza ogólne informacje za Besserem. Poleca zbierać fragmenty, przekroje podłużne i poprzeczne pni drzew i gałęzi krzewów, a także ich korę. Rośliny powinno się zbierać co najmniej w dwóch egzemplarzach (jeden do zasuszenia, drugi do oznaczania), zaś kwiaty - w różnych fazach rozwoju (w pączkach, zupełnie rozwinięte i opadające). Jeśli liście korzeniowe, łodygowe i kwiatowe się różnią, należy zebrać je wszystkie. Autor, jako pierwszy w polskiej literaturze botanicznej, wskazuje sposób zbioru i suszenia mchów, zaleca zbieranie całych kępek, z wyjątkiem tych, które rosną pojedynczo, $\mathrm{z}$ fragmentem podłoża na którym rosły. Wodorosty trzeba zbierać do małych baniek z wodą, inaczej szybko wysychają i ulegają zniszczeniu, natomiast porosty - z kawałkiem kory lub kamienia na którym rosną, w porze wilgotnej; w tym czasie pęcznieją od wilgoci i stają się giętkie, gdyż suche łatwo się kruszą. Grzyby również powinny być zbierane z tą częścią rośliny na której rosły. Do zasuszania roślin autor zaleca stare gazety. Kwiaty o delikatnym zabarwieniu przekłada się kawałkami papieru zwyczajnego lub listowego. Korony roślin wargowych układa się na bok, aby wyraźnie było widać cechujące je części (ziew, wargę dolną i górną), podobnie jak korony motylkowych, pozostawiając je jednak w naturalnym położeniu. Niektóre rośliny są niezwykle kruche i często przy rozkładaniu do suszenia ulegają połamaniu. Takie rośliny należy rozkładać kiedy już podwiędną. W opisie kwiatów, których barwy szybko ulegają wyblaknięciu Ślendziński podaje informacje zaczerpnięte z Botaniki ... KLUKA (1785). W przypadku wodorostów i ramienic poleca zanurzyć pod roślinę arkusz papieru wraz z drewnianą deseczką (arkusz musi być mokry, aby się nie odklejał) i stopniowo podnosić, aby woda spływała, a wodorost pozostał. Po wyschnięciu wodorosty przylgną do kartki, jakby przyklejone. Nieco odmienny niż poprzednicy sposób postępowania proponuje względem grzybów, które należy przecinać wzdłuż na połowy. Następnie z jednej z połówek ścina się cienką wewnętrzną warstewkę kapelusza i trzonu, a z drugiej połowy (kapelusz i trzon) ścina się warstwę naskórka. Tak pobrane „płaskórki” suszy się w papierze, a po wysuszeniu nakleja na papier jedną obok drugiej za pomocą gumy arabskiej. Podobnie autor zaleca postępować z wycinkami z grubych, mięsistych owoców. Oprócz tego namawia do posiadania zbioru całych wysuszonych owoców, które należy przechowywać w osobnych skrzynkach. Opisując sposoby suszenia, wspomina o roślinach bardzo delikatnych, np. kosaciec, które często ulegają pomarszczeniu i pokruszeniu. Takie rośliny raz ułożone, powinno się przekładać często razem $\mathrm{z}$ arkuszami pomiędzy puste i suche, nie przyciskając ciężarem. Zwraca uwagę, iż w czasie suszenia roślina zbyt silnie uciśnięta zmienia swój charakterystyczny kształt.

Po odpowiednim zasuszeniu, rośliny przenosi się do zielnika na pojedyncze arkusze papieru. Kartki muszą być tej samej wielkości, na każdy arkusz kładzie się tylko jeden gatunek. Rośliny na arkuszach należy przymocować paskami z papieru, które na końcach przykleja się gumą do arkusza. Paczki z nasionami umieszcza się na arkuszach obok roślin, do których należą. Mchy można przechowywać na arkuszach, drobne zaś gatunki zwijać w paczki papierowe i wkładać w arkusze, podobnie jak nasiona. Ważną kwestią podnoszoną przez autora jest również oznaczenie liczb porządkowych na każdym arkuszu zawierającym rodzaj i na arkuszach zawierających rodziny. Prócz tego umieszcza się spis wszystkich rodzajów na początku zielnika. Do tego powinien być jeszcze dołączony alfabetyczny, kartkowy spis wszystkich rodzajów, znajdujących się w zielniku i przed każdym 
rodzajem zapisana liczba porządkowa rodziny, do której należy. W końcowej części Ślendziński omawia ochronę przed pyłem i wilgocią. Uświadamia, iż zabrudzone pyłem rośliny trudno oczyścić, ponieważ suche łatwo ulegają pokruszeniu, a drobne fragmenty, jak włoski i gruczoły, zupełnie można zniszczyć. Zawilgocone rośliny tracą swoją barwę, czernieją i pokrywają się pleśnią, której można się pozbyć działając temperaturą $60^{\circ}$, barwy jednak nie da się poprawić. Do zabezpieczenia przed szkodliwymi owadami zaleca stosować kwas karbolowy, umieszczany w zamoczonej gąbce między arkuszami. Do przyklejania grzybów, mchów i innych roślin należy używać zatrutego kleju.

W 1883 r. Kazimierz Filipowicz (1845-1891) publikuje na łamach Wszechświata obszerny (w 15 numerach) artykuł pt. „Rośliny Skrytokwiatowe (Cryptogamae), opisanie ich budowy, tudzież sposobów zbierania, preparowania i badania” (FILIPOwICZ 1882, 1883). Całość poświęcona jest wodorostom, porostom, grzybom, wątrobowcom oraz mchom. W jednej z części wspomnianego artykułu opisuje przybory niezbędne do zbioru wątrobowców oraz porę zbioru. Za szczególnie wartościowe uważa zbieranie głównie wiosną i jesienią, kiedy ze względu na większą wilgotność znaleźć można dobrze wykształcone egzemplarze. W czasie wycieczki botanicznej powinno się zbierać całe „murawki” zdjęte z podłoża i wkładać je do teki między bibułę. Powróciwszy z wycieczki należy oczyścić każdy okaz z przylegających igieł, kawałków drzewa i owadów. Następnie okazy suszy się w bibule pod delikatnym naciskiem. Niektóre gatunki bardzo drobne i delikatne zaleca - wzorem poprzedników - zbierać z kawałkiem podłoża, na którym rosły. W późniejszym czasie praca wyszła w odbitce (FILIPOWICZ 1884), jako osobna książeczka (MAJEWSKI 2005). Podobnie jak w Wszechświecie została opatrzona sześcioma litografowanymi tablicami, przedstawiającymi szczegóły morfologiczno-anatomiczne wybranych grup taksonomicznych. Obecnie to duża rzadkość bibliograficzna.

Stanisław Dawid (1861-1917), botanik, absolwent Cesarskiego Uniwersytetu Warszawskiego, chcąc ułatwić początkującym florystom postawienie pierwszych kroków w dziedzinie poznania roślin, publikuje na łamach Wszechświata artykuł „Herboryzacja czyli zbieranie, określanie i zasuszanie roślin” (DAWID 1885). W początkowej części tekstu uświadamia czytelnikowi wartość wycieczek botanicznych, które zaleca początkowo podejmować w rejonach bliższych miejsca zamieszkania. Wycieczki takie, jak podkreśla, należy rozpocząć ,jak tylko ustaną mrozy, zniknie śnieg i ziemia trochę podeschnie, t.j. w ostatnich dniach Marca lub na początku Kwietnia; najlepiej [zbierać] pierwsze rozkwitające okazy, przy takiem bowiem postępowaniu mniej mamy szans pominięcia jakiejś rzadszej lub prędko przekwitającej rośliny. Przeciągnąć można wycieczki do początku zimy, a można je odbywać nawet zimą w celu zbierania okazów drzew i krzewów, albowiem te możemy oznaczać z kształtu, sposobu osadzenia i innych cech pączków zimowych". Rośliny zbierane w południe, w czasie upału, bardzo szybko więdną; aby im przywrócić naturalny wygląd, trzeba wstawić je do wody z dodatkiem saletry sodowej (łyżeczka saletry na dwie szklanki wody). Autor twierdzi, że wycieczki botaniczne powinno odbywać się samemu: ,albo też tylko w nielicznym towarzystwie i to osób interesujących się przedmiotem, w przeciwnym bowiem razie postronna rozmowa, śmiechy i t.p. odrywają uwagę florysty od głównego dlań przedmiotu”. Zwraca uwagę, aby przy zbieraniu roślin pasożytniczych dołączać do nich i te, na których żyją, a przy roślinach wijących się nie pomijać 
tych, wokół których się owijają. Rośliny zbierane do botanizerki ${ }^{1}$ lub teczki powinny być oczyszczone z pyłu, owadów, ich jajeczek i gąsienic; rośliny uszkodzone radzi autor pozostawić, a zebrać zdrowe i całe okazy.

Jako pierwszy w naszej literaturze poświęconej zbiorom zielnikowym, zwraca uwagę na liczbę pozyskiwanych egzemplarzy rzadkich roślin. Przestrzega przed nadmiernym i niepohamowanym zbieractwem roślin, które może przyczynić się do zniszczenia lub znacznego zubożenia populacji poszczególnych taksonów: „Początkujący florysta zwykle stara się zebrać jak najwięcej egzemplarzy tej samej rośliny, tymczasem jeden albo dwa dobre okazy wystarczą zupełnie do oznaczenia i zasuszenia. Regułę tę w szczególności ściśle stosować należy do roślin rzadkich, które w skutek podobnego barbarzyńskiego traktowania często bywają zupełnie wyniszczone w pewnej miejscowości”. Podaje również wiele nowych, wcześniej nieznanych w polskiej literaturze, praktycznych wiadomości, na podstawie niemieckich opracowań Wilkomma, Lüdersdorfa i Schmidlina. W przypadku roślin wydzielających lepki sok, np. rosiczki, zaleca posypanie proszkiem likopodyjum (zarodniki widłaka), który po wysuszeniu roślin łatwo daje się zdmuchnąć, zaleca również suszyć je w papierze woskowym albo naoliwionym, lub też przemyć przed układaniem spirytusem. W przypadku większości roślin o barwie niebieskiej, po pewnym czasie, kwiaty brunatnieją i ciemnieją. Aby temu zapobiec, autor radzi zamoczyć je w mocnym spirytusie; utraconą barwę można im przywrócić mocząc kwiaty w słabym kwasie azotowym. Miejsce suszenia powinno być suche, ciepłe i przewiewne. Wymienia sześć gatunków szkodników, przez które zasuszone rośliny bywają narażone na zniszczenie. Dla uniknięcia strat, radzi zanurzać lub zraszać rośliny roztworem sublimatu w spirytusie, co, jak sam podkreśla, jest czynnością niebezpieczną.

W 1886 r. w Krakowie ukazuje się podręcznik Botanika szkolna dla klas niższych autorstwa Józefa Rostafińskiego (1850-1928) (RostAFIŃski 1886). Do podręcznika dołączony był bezpłatny dodatek, zawierający dwa klucze do oznaczania naszych pospolitych roślin, który uznany został za pierwsze wydanie publikowanego później wielokrotnie przewodnika, stanowiącego już osobną publikację. W początkowym fragmencie klucza zatytułowanym: „O zbieraniu, badaniu i suszeniu roślin kwiatowych” autor zamieszcza elementarne wiadomości dotyczące metodyki zbierania, suszenia oraz oznaczania roślin. Te podstawowe informacje, napisane prostym, zrozumiałym językiem, w znaczący sposób przyczyniły się do popularyzacji tworzenia zielników wśród licznej rzeszy młodych adeptów botaniki. Wiadomości dotyczące zbioru roślin i tworzenia zielników były zamieszczone w czterech kolejnych wydaniach przewodnika (RosTAFińsKi 1886, 1901, 1906, 1911).

Ciekawym, lecz sporadycznie spotykanym w bibliotecznych zbiorach jest krótki, bo zaledwie dziewiętnastostronicowy przewodnik, pt. Zbieranie roślin i urzq̨dzenie ziel$n i k a^{2}$ (Ryc. 4), autorstwa Wieńczysława Łosia (1868-1905) (Łoś 1888). Wydany został w Pizie, gdzie autor podjął studia na Wydziale Przyrodniczym tamtejszego uniwersytetu

\footnotetext{
1 Autor bardzo szczegółowo opisuje botanizerkę czyli puszkę botaniczną - jej kształt, wielkość, budowę, wykorzystanie, a nawet podaje cenę za jaką można ją kupić.

2 W 2000 r. został wydany reprint tego wydania przez Fundację Ośrodka Edukacji Ekologicznej, różniący się od oryginalnego wydania szatą graficzną okładki.
} 
(studiował w latach 1887-1889), jednak brak pewnych informacji co do ich ukończenia. Dwa lata później ukazało się drugie, rozszerzone wydanie przewodnika. Oprócz opisu zbioru i suszenia roślin, autor dodał część poświęconą entomologii. Przewodnik ten wzorowany był w znacznym stopniu na podręczniku Aleksandra Ślendzińskiego, uwzględniał również informacje zaczerpnięte z Botaniki Krzysztofa KLuKA (1785) oraz artykułu Stanisława DAwIDA (1885).

W kolejnym roku ukazał się w warszawskim czasopiśmie - Pamiętniku Fizyograficznym artykuł autorstwa Franciszka Błońskiego (18671910) Conspectus Muscorum Poloniae. Mchy Królestwa Polskiego część I (Błoński 1889). Publikacja zawiera rozdział poświęcony zbieraniu i „określaniu” mchów. Informacje w niej zawarte w dużej mierze są powtórzeniem wiadomości już wcześniej publikowanych. Oprócz opisu dotyczącego metodyki zbioru i suszenia, autor szczegółowo omawia ich oznaczanie, zaleca również dodatkowo umieszczenie rysunków różnych części mchów, szczególnie liści.

W 1890 r. Ignacy Szyszyłowicz (1857-1910) ogłosił krótką wiadomość pt. Nowy sposób konserwowania kwiatów (SZYSZYŁowICZ 1890).

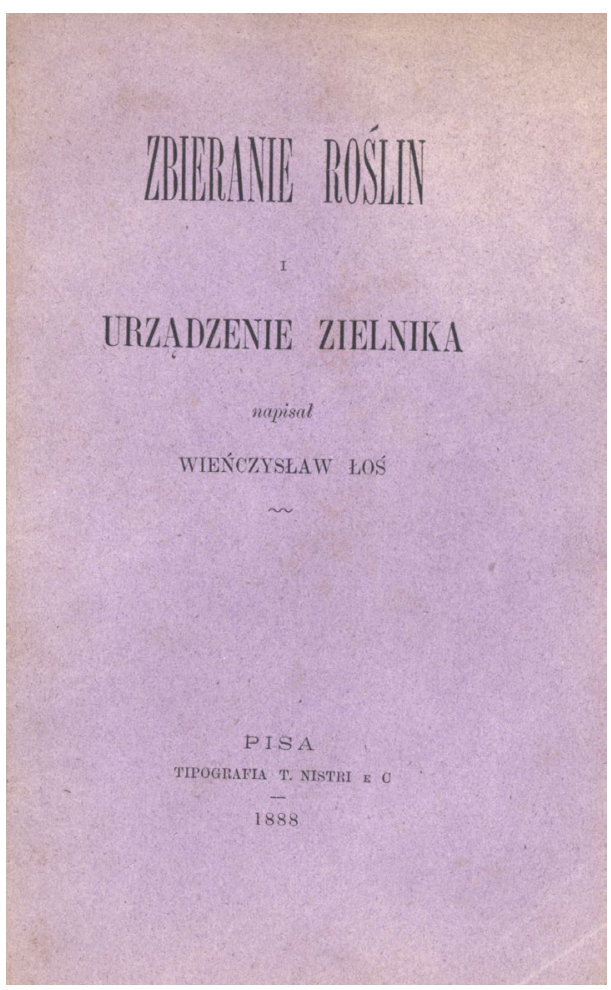

Ryc. 4. ,Zbieranie roślin i urządzenie zielnika” Wieńczysława Łosia (1888)

Fig. 4. Plant collection and herbarium organization by Wieńczysław Łoś (1888)

Autor na podstawie własnych doświadczeń opracował metodę konserwacji kwiatów roztworem naftaliny w benzynie. Zaleca tą metodą konserwować zwłaszcza „kwiaty bardzo delikatne o płatkach cienkich i wiotkich, jak fiołki, azalie, akacje". Twierdzi, iż barwy odcieni niebieskich, czerwonych i żółtych, które zwykle szybko ulegają zblaknięciu, doskonale zachowują pierwotne zabarwienie właśnie dzięki tej metodzie. Ostrzega również przed możliwymi niebezpieczeństwami związanymi ze stosowaniem opisanej metody: „dla mniej ostrożnych, lub nieświadomych dodać muszę uwagę, aby podczas wszelkich tych operacji starannie unikali ognia, najmniejsze bowiem zbliżenie tegoż do ulatniających się par benzyny wywołuje silną i nader niebezpieczną eksplozją". Poleca tę metodę nie tylko ,przyrodnikom, ale i paniom”, które ,zamiast męczyć nieszczęsne kwiaty po książkach mogą przechowywać je w postaci tak świeżej, jak gdyby dopiero co były zerwane z krzaków".

W końcu XIX w., na łamach Kosmosu ukazała się odezwa, zachęcająca do nawiązania współpracy w zakresie nowo wydawanego Zielnika Flory Polskiej (ReHMAn \& WoŁoszCZAK 1891). Autorami odezwy byli lwowscy profesorowie: Antoni Rehman (1840-1917) oraz Eustachy Wołoszczak (1835-1918). W odezwie autorzy krótko sprecyzowali sposób, w jaki rośliny mają być zbierane, suszone oraz oznaczone. 
W nieco późniejszym czasie Władysław Dybowski (1839-1910) opublikował Skorowidz do Zielnika Flory Polskiej (DyBowski 1899), w którym pokrótce nakreślił historię badań florystycznych na dawnych i obecnych ziemiach polskich, natomiast bardzo szczegółowo opisał przygotowanie roślin do zielnika, jak również zaznaczył, jakie informacje powinny znajdować się na etykietach.

\section{PUBLIKACJE NA TEMAT SPOSOBÓW TWORZENIA ZIELNIKÓW - XX w.}

Początek XX w. przynosi ożywienie nauk przyrodniczych, w tym i botaniki. Modnym i coraz popularniejszym zajęciem staje się zbieranie, oznaczanie, suszenie roślin oraz sporządzanie zielników. Zajęciom tym oddawały się zwłaszcza młode, wykształcone kobiety. Dzięki studiom prywatnym lub samokształceniu, przyczyniały się do poznawania szaty roślinnej rodzimego kraju poprzez publikowane samodzielne przyczynki lub też dostarczanie materiałów specjalistom. W tym czasie powstaje dużo przystępnych publikacji dotyczących sporządzania zielników, często w postaci książek kieszonkowego formatu, co ułatwiało korzystanie z nich w terenie. Prace te ogłaszane w języku polskim, w różnych zaborach, oprócz kompilacji informacji dotyczących: zbioru, oznaczania (w tym także spisu literatury fachowej), suszenia, porządkowania, przechowywania oraz przesyłania zielników, zawierały rysunki potrzebnych narzędzi, niezbędnych w czasie wycieczek botanicznych i samego „botanizowania”.

W 1905 r. ukazały się w Warszawie dwa tomy kieszonkowego formatu, wydane w ramach serii wydawniczej Ksiażki dla wszystkich (Ryc. 5), niezwykle popularnej wśród społeczeństwa. Autorką była znana popularyzatorka nauk przyrodniczych Maria Arct-Golczewska (1872-1913), córka znanego i cenionego księgarza i wydawcy Michała Arcta. Pierwszy tom (o numerze 205) pt. Wskazówki do zbierania roślin i uktadania zielnika, został opracowany według angielskich podręczników autorstwa K. G. Lutze ${ }^{3}$ (ARCT-GolCZEwSKA 1905). Zawierał on podstawowe informacje o organach roślinnych, ich budowie oraz znaczeniu. Poszerzony był o rysunki oraz liczne wskazówki dotyczące zbierania, oznaczania oraz układania zielnika. W pracy tej po raz pierwszy zamieszczona została informacja o drucianej teczce służącej do zbioru i suszenia roślin' ${ }^{4}$. Drugi tom (o numerze 206) zawierał gotowe etykiety zielnikowe do wycięcia i przyklejenia na arkusz zielnikowy (Ryc. 5) (ARCT-GoLCZEWSKA 1905). Na każdej etykiecie dotyczącej gatunku jest nazwa polska i łacińska z autorem, przygotowane miejsce na datę i miejscowość zbioru. Oprócz etykiet gatunkowych są również etykiety dotyczące rodzin botanicznych. W tomie zamieszczono na 128 stronach druku 1230 nazw roślin. Jest to unikatowy druk, który nigdy wcześniej ani później nie miał odpowiednika w krajowej literaturze botanicznej. Jedenaście lat później, już po śmierci autorki, ukazało się drugie wydanie pierwszego tomu (ARCTównA \& TRZEBIŃsKi 1916) o nieznacznie zmienionym tytule, poprawione przez Józefa Trzebińskiego (1867-1941).

\footnotetext{
3 Informacja o pierwowzorze opracowania została zawarta na stronie tytułowej pierwszego tomu (o numerze 205) pt. Wskazówki do zbierania roślin i układania zielnika.

4 Metoda zbioru roślin i suszenia w drucianych teczkach była propagowana przez Józefa Mądalskiego, który poprzez wydanie dwóch prac (MĄDALSKI 1951, 1955) znacząco przyczynił się do jej upowszechnienia.
} 

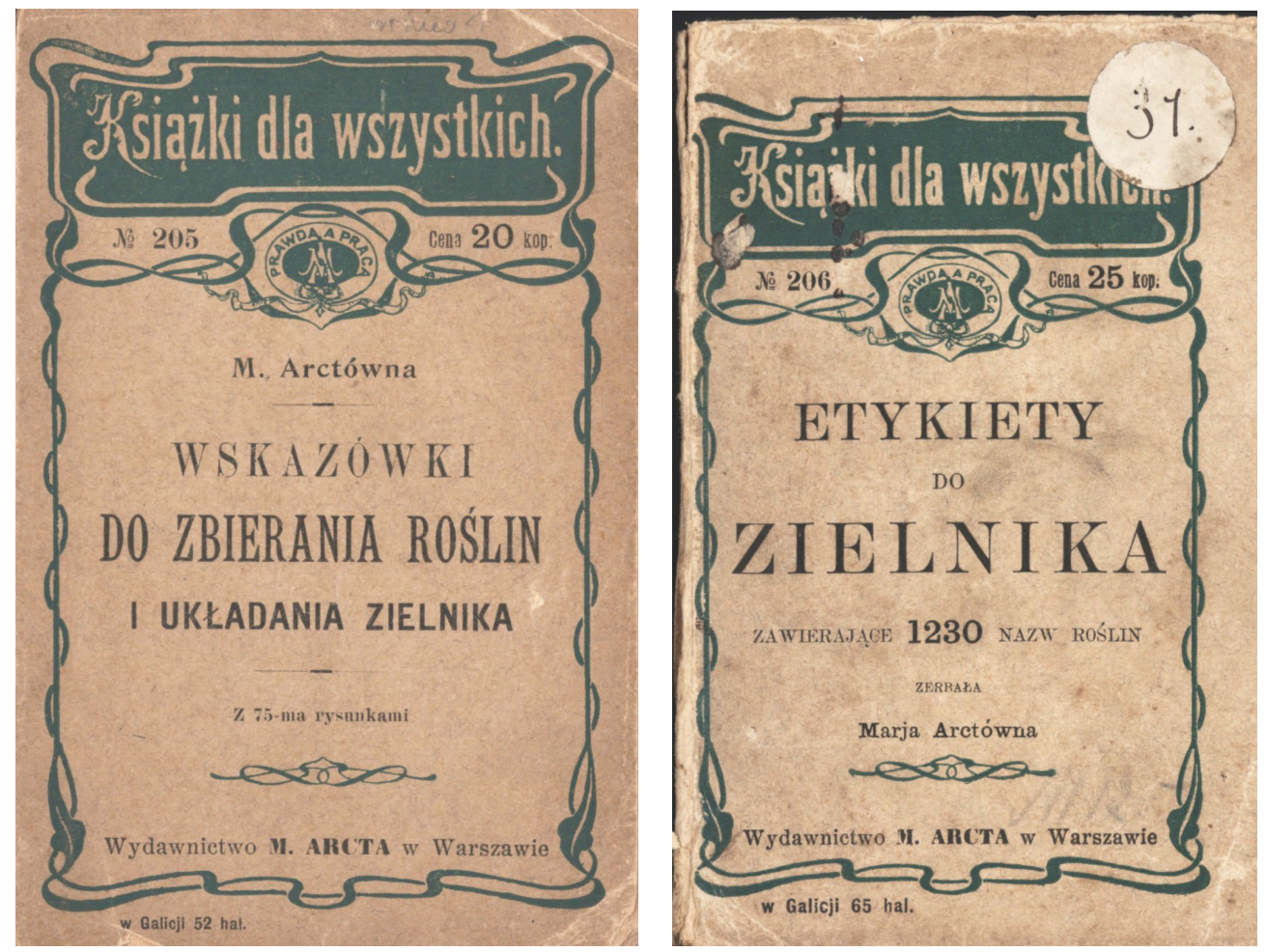

Ryc. 5. Wydawnictwa z serii „Książki dla wszystkich” autorstwa Marii Arctówny (ARCT-GoLCZEwSKA 1905)

Fig. 5. Publications from the series Books for everybody by Maria Arctówna (ARCT-GolCZEwSKA 1905)

Kolejną i niezwykle ciekawą pozycją, również wydaną w 1905 r., jest książka pt. Zielnik. Podręcznik dla zbierajacych rośliny (BoJKo 1905) (Ryc. 6), autorstwa Piotra Bojko (?-?) ${ }^{5}$ (BRzozowski 1984). Książka kieszonkowego formatu $(10 \times 15 \mathrm{~cm})$ liczy 56 stron. Została wydana w Złoczowie przez księgarza i wydawcę Wilhelma Zukerkandla (ANONIM 1971) w ramach serii Biblioteki Powszechnej nr 524. Książka dedykowana jest Edwardowi Zubkowiczowi (?-?) na ,pamiątkę naszych wycieczek botanicznych na pierwszym roku”. We wstępie autor nadmienia, iż wzorował się na niemieckiej pracy Anleitung zum rationellen Botanisieren B. Auerswalda, oraz pracach J. Rostafińskiego i E. Warminga (1841-1924). W korekcie i uzupełnianiu tekstu o ,cenne rady” uczestniczył Bronisław Błocki (1854-1919) oraz Adam Gottwald (?-?), który był współautorem ostatniego rozdziału.

Książka zawiera podstawowe informacje na temat zbioru roślin z różnych grup systematycznych, ich suszenia i przechowywania. W przypadku bardzo drobnych glonów Bojko radzi, aby je od razu kłaść na „,szklane tafelki” (szkiełka podstawowe), których powszechnie używa się do robienia preparatów mikroskopowych, a które w późniejszym czasie

5 O samym autorze brak szczegółowych informacji, wiadomo tylko, iż był autorem dwóch książeczek o tematyce przyrodniczej oraz upowszechniał tłumaczenia łacińskie. BRzozowski (1984) zamieszcza informacje, iż Piotr Bojko, Adam Gottwald, Edward Zubkowicz byli z wykształcenia leśnikami, po nauce w Krajowej Szkole Gospodarstwa Lasowego we Lwowie. Bojko i Zubkowicz studiowali tam w latach 1901-1905, a Adam Gottwald rok krócej, w latach 1901-1904. 


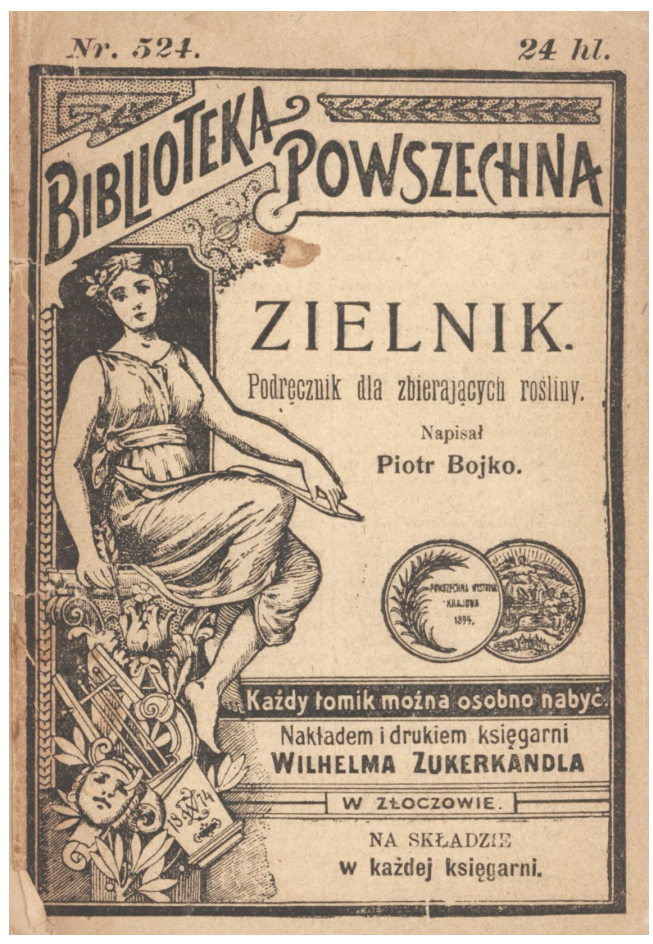

Ryc. 6. Okładka pracy autorstwa Piotra BOJKO (1905)

Fig. 6. Cover of a book by Piotr BoJko (1905)

można od razu dać pod mikroskop. W celu zabezpieczenia tak powstałego „preparatu” radzi przykryć go szkiełkiem nakrywkowym. W przypadku grzybów zaleca dwa sposoby zbioru. Twarde otoczniowate (Pyrenomycetes), rosnące na suchych gałęziach, zbożu (Claviceps purpurea, sporysz) oraz niektóre $\mathrm{z}$ miseczkowatych (Discomycetes) zbiera się razem $\mathrm{z}$ podłożem. Grzyby mikroskopijne rosnące na żywych liściach (np. róży, chmielu, grochu), m.in. mączniaki (Erysiphaceae) zbiera się i suszy razem z liśćmi. Bardzo delikatne grzyby (niektóre gatunki drobnych purchawek, Gasteromycetes) przechowuje się w małych probówkach lub flaszeczkach. Autor zaznacza, że preparowanie do zielnika grzybów kapeluszowych jest żmudne i często zawodne. Aby zabezpieczyć zbiory przed szkodnikami zaleca zastosowanie środków dezynfekcyjnych oraz zatrucie preparatów. Podsumowując autor pisze, że w prawidłowo założonym zielniku ,rośliny w nim przechowywane powinny, o ile możliwości, zatrzymać swój naturalny wygląd, a zielnik winien być tak uporządkowany, by się w nim łatwo i w każdej chwili można było wyznać".

Kolejnym opracowaniem na temat zbierania roślin i układania zielnika, wydanym na początku XX w. jest praca wileńskiego botanika Jana Kazimierza Muszyńskiego (18841957) - 39-stronnicowa broszura pt. Jak należy zbierać rośliny i układać zielniki ${ }^{6}$ (MuszYŃSKI 1908). W przedmowie autor wskazuje na palącą konieczność powstania tego rodzaju dzieła i jego praktycznego zastosowania: „I u nas wiek XX zaczyna być według określenia Ellen Key - „wiekiem dziecka”. Zaczęliśmy zwracać większą uwagę na wychowanie młodzieży i zrozumieliśmy, że rozwój intelektualnych zdolności człowieka odbywa się najlepiej nie w oderwaniu od przyrody lecz w najściślejszym obcowaniu z nią. Nauki przyrodnicze odzyskały przynależne im stanowisko w programach szkół, a w młodem pokoleniu rozbudzonem zostało zamiłowanie do badania przyrody, lecz postępom tego ostatniego zjawiska stoi dziś jeszcze na przeszkodzie brak odpowiedniej literatury w naszym języku; brak będący następstwem poprzedniej obojętności dla nauk przyrodniczych. Choć w ostatnich czasach stworzono kilka klasycznych podręczników, jednak wiele działów czeka jeszcze swojej kolei. Jednym z takich brakujących nam podręczników jest zbiór wskazówek o zbieraniu roślin i przechowywaniu ich w zielnikach".

\footnotetext{
6 Praca ukazała się w 1908 r. nakładem Towarzystwa Wzajemnej Pomocy „Farmacja”, a wydrukowana była przez Tłocznię Wł. Łazarskiego w Warszawie. Wydana ponownie w Wilnie w 1928 r.
} 
We wstępie autor zwraca uwagę na korzyści płynące ze zbierania zielników i zachęca do ich gromadzenia. Podkreśla naukową wartość dobrze zebranych, zasuszonych i opatrzonych etykietami roślin. Szczególną uwagę zwraca na przedmioty potrzebne w trakcie zbierania roślin. Na wycieczkę dłużej trwającą poleca zabrać ze sobą pudełeczka, np. po zapałkach, do zbioru mchów, wątrobowców, porostów oraz niewielką liczbę słoików, flaszek lub probówek do zbioru wodorostów i grzybów pasożytniczych oraz siateczkę z gęstego muślinu do chwytania roślinnego planktonu. Niezmiernie ważnym przyborem jest druciana siatkowa lub drewniana praska, która jednocześnie służy do zbierania i suszenia roślin. Kolejnymi przyrządami są: szczypczyki (pinceta), igły w oprawie, szczegółowa mapa miejscowości oraz zapas etykiet do notowania. W dalszej części pracy autor opisuje czas, miejsce i porę zbierania różnych grup roślin. Podkreśla, iż rośliny w zależności od przynależności systematycznej możemy zbierać cały rok: porosty i mchy na początku wiosny i zimą, wodorosty wczesną wiosną lub późną jesienią, grzyby pod koniec lata i ciepłą jesienią, a od marca - rośliny kwiatowe. Muszyński zaleca zbierać po kilka okazów, gdyż jak stwierdza „do określenia trzeba nam zepsuć niektóre części rośliny, np. kwiaty, owoce, a zatem trzeba posiadać egzemplarze zapasowe, które mogą się również przydać do wymiany na odmienne okazy z innymi zbieraczami”. Zwraca również uwagę, aby zbiory nie prowadziły do zbytniego wyniszczenia rzadkich przedstawicieli niektórych paprotek, widłaków czy storczyków, pojawiających się często w bardzo ograniczonej ilości. Rośliny wodne, posiadające miękkie listki plączące się w bezładną masę przy wyjmowaniu z wody, trzeba układać na arkuszu papieru od razu pod wodą. W tym celu używa się papieru woskowanego. Rośliny wyjmuje się delikatnie, aby nie zrzucić rośliny z wodą, resztę odsącza się delikatnie i układa między arkusze papieru do suszenia. Jagody i soczyste owoce umieszcza się między kawałkami woskowanego papieru, wygniótłszy uprzednio soczystą zawartość. Nasiona należy zbierać do papierowych kapsułek, które potem zostaną przymocowywane do arkuszy zielnikowych. W przypadku wierzb, topoli i innych rozdzielnopłciowych roślin trzeba oddzielnie zebrać gałązki z ich kwiatami. Dalej wymienia klucze do oznaczania roślin: polskie, rosyjskie i niemieckie (podaje ich ceny oraz miejsce, gdzie je można kupić), pomocne w znacznym stopniu w oznaczeniu okazów zielnikowych. Grzyby soczyste, śluzowce, wodorosty zaleca konserwować w 60-70\% spirytusie lub w 5\% roztworze formaliny. W przypadku grzybów zaleca również tradycyjne suszenie i dołączenie akwarelowego rysunku okazu, ponieważ grzyby przy suszeniu często zmieniają barwę. Jeśli nie posiadamy farb, należy dokładnie opisać barwę świeżego okazu na załączonej do zielnika karteczce. W przypadku roślin drzewiastych ze sterczącymi kolcami zgniata się je między dwiema deskami.

W 1911 r. Marian Raciborski (1863-1917), na łamach lwowskiego Kosmosu ogłosił artykuł „Wskazówki dla zakładających muzea przyrodniczo-krajoznawcze” (RACIBORSKI 1911). Jeden z rozdziałów poświęca zbiorom botanicznym, ich gromadzeniu, suszeniu i przechowywaniu ${ }^{7}$. Pisze że: „Najpraktyczniejszy jest format $47 \times 30 \mathrm{~cm}$ dla roślin naczyniowych, a dla roślin niższych format zwykłego arkusza". Według autora należy prowadzić

\footnotetext{
7 Według Bolesława Hryniewieckiego, część botaniczną artykułu Raciborskiego, dotyczącą zielników opracował Stanisław Fedorowicz. Hryniewiecki informację tę zawarł w książce Poradnik dla samouków T. VI, Botanika część I, s. 163.
} 
dwa zielniki: jeden systematyczny, gdzie rośliny ułożone będą według pokrewieństwa, drugi nazwany ekologicznym, ułożony według występujących zbiorowisk np. „dąbrowy, a więc dęby i całe mnóstwo krzewów, krzewinek i ziół, tworzących podszycie lasu”. Zielnik może również być zestawiony według roślin charakterystycznych dla różnych rodzajów gleb, np. gleby wapiennej, gliniastej, piaszczystej (wydmy) i miejsc słonych. Autor wymienia przyrządy służące do zbierania roślin: puszka duża blaszana do noszenia ich na wycieczkach, siatka planktonowa tudzież odpowiednia liczba słoików szklanych lub probówek. Plankton i glony zaraz po zbiorze zaleca zalać 3\% roztworem formaliny. Zwraca uwagę, aby zbierać po 6-10 sztuk roślin każdego gatunku, w różnych stadiach rozwojowych, początkowo przekładając je co kilka godzin (2-3 razy na dobę), później coraz rzadziej, aż do wysuszenia. W przypadku roślin mięsistych, np. rozchodnika, łuskiewnika, radzi sparzyć je gorącą wodą. Mchy, wątrobowce oraz mniejsze grzyby zaleca suszyć tak samo, nie ściskając ich zbyt mocno. $Z$ większych grzybów należy robić ich cienkie przekroje; ten sposób służy również do roślin będących pasożytami kwiatowymi, a jeśli zaczęłyby czernieć, należy dodać podsiarczanu sodowego. Wyjątkowo małe glony, jak okrzemki lub wstężnice, suszy się na blaszkach miki na powietrzu. W 1917 r. artykuł ten został wydany przez Polskie Towarzystwo Krajoznawcze, oddział Lubelski, jako cienka 29-stronnicowa broszura pt. Wskazówki dla gromadzacych zbiory krajoznawcze bez nazwiska autora (ANONIM 1917).

W tym samym czasie ukazała się praca Józefa Trzebińskiego Jak zbierać i oznaczać rośliny - praktyczne wskazówki do oznaczania i urzqdzania zbiorów roślin kwiatowych $i$ zarodnikowych z podaniem ważniejszej literatury (TRZEBIŃSKI 1917). Wydana została nakładem M. Arcta w Warszawie, a ciekawostką jest fakt, iż posiada dwie wersje okładki, różniące się nieco szatą graficzną (Ryc. 7). Autor zwraca uwagę głównie na praktyczne aspekty związane ze zbiorem roślin w terenie. Dużo uwagi poświęca omówieniu kluczy, flor oraz atlasów botanicznych przydatnych do oznaczania różnych grup roślin. Po raz pierwszy wprowadza pojęcie zielnika biologicznego, który według niego ma obrazować różne właściwości zewnętrzne roślin, będące wynikiem ich przystosowań do środowiska. Wspomina również o zielnikach fitopatologicznym i teratologicznym oraz o zielniku roślin uprawnych. Nieco później (w 1919 r.) na podstawie referatu Trzebińskiego, zostaje opracowana część poświęcona florystyce, zamieszczona w broszurze Polskiego Towarzystwa Krajoznawczego pt. Metodyka wycieczek krajoznawczych (ANONIM 1919), która nieznacznie różni się treścią od opisanej pracy Trzebińskiego.

W 1922 r. ukazuje się obszerna monografia Zielnik $i$ muzeum botaniczne Bolesława Hryniewieckiego (1875-1963) (HRYNIEWIECKI 1922), wydana w Krakowie, drukiem W. L. Anczyca i Spółki. Autor wzorem poprzedników wylicza oraz szczegółowo omawia niezbędne narzędzia potrzebne podczas botanizowania, podkreślając ich zalety i wady. W dalszej części omawia zbieranie okazów, wskazuje iż najbardziej interesujące są miejsca naturalne, dziewicze, nie dotknięte ręką ludzką. Istotną kwestią według autora jest czas zbioru (pora dnia) w zależności od gatunku, np. Hieracium najlepiej zbierać do południa, ponieważ wtedy są otwarte koszyczki. Wskazuje możliwość uprawy roślin do zielników, dzięki czemu możemy uzyskać różne stadia wzrostu rośliny i przy okazji je obserwować. Opisuje różne sposoby utrwalania okazów. Interesujące jest propagowanie przez autora suszenia roślin w piasku, dzięki czemu uzyskuje się naturalne położenie względem siebie części 
roślin (autor wskazuje na możliwość wykorzystania ich jako modeli). W zielniku zaleca wzmocnienie zagięć zasuszonych okazów przy pomocy kawałka papieru z nacięciem, a dla takich roślin, jak łuskiewnik (Lathraea squamaria L.) czy korzeniówka (Monotropa hypopitys L.) krótkie (10-15 minutowe) moczenie w gotującej się wodzie, dzięki czemu nie czernieją. Gałązki roślin iglastych (np. świerka), radzi moczyć kilka dni w wodzie, a następnie w glicerynie, dzięki czemu igły nie ulegają osypaniu, a do przytwierdzenia okazu do arkusza poleca wykorzystać klej stolarski. Autor zwraca również uwagę na dezynsekcję zbiorów za pomocą alkoholu z sublimatem, pary siarczku węglowego lub czterochlorku węglowego. Zwraca uwagę, że wszystkie paczki z okazami należy przechowywać w postaci poziomej, nigdy pionowej, ponieważ wtedy okazy się niszczą, a etykiety wypadają. Omawia również sposoby przetrzymywania roślin i ich owoców w płynach. W kolejnych rozdziałach charakteryzuje muzeum botaniczne, oznaczanie roślin, wskazuje specjalistyczną literaturę naukową oraz szczegółowo opisuje dostępne

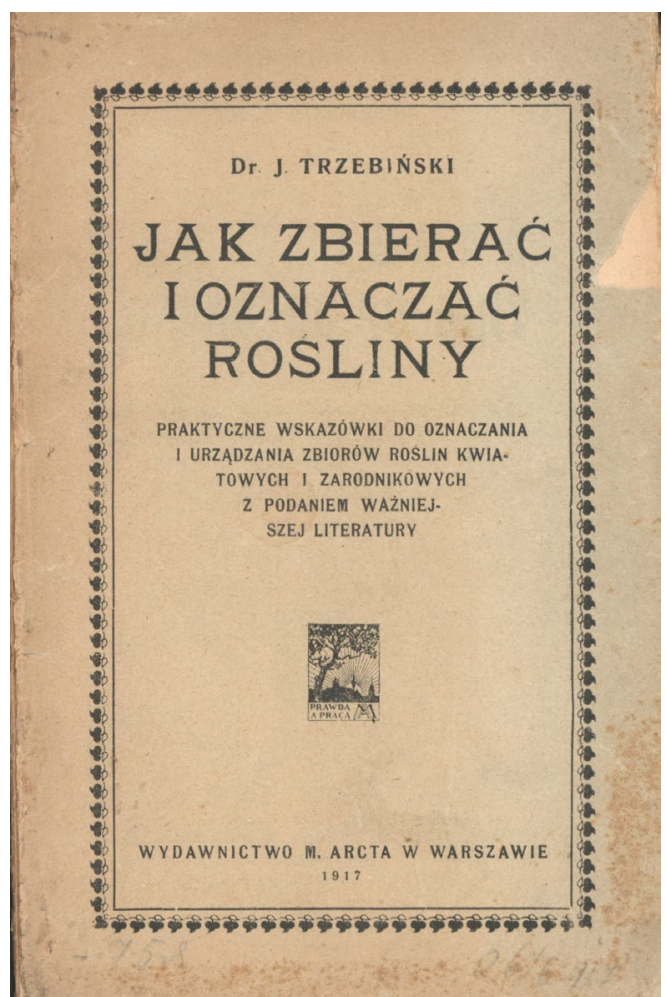

Ryc. 7. Okładka instrukcji autorstwa Józefa TrZEBIŃSKIEGO (1917)

Fig. 7. Cover of manual by Józef TRZEBIŃSKi (1917) klucze i flory, atlasy botaniczne, również monografie poświęcone poszczególnym taksonom.

W 1924 r. ukazuje się praca Jerzego Cienciały (1884-1940) w ramach serii Samouczek Techniczny, wydawnictwo popularnonaukowe pt. Zbieranie, zasuszanie i przechowywanie roślin (CIENCIAŁA 1924). Autor w książce kieszonkowego formatu uzasadnia korzyści wynikające ze sporządzania zielnika, opisuje najważniejsze narzędzia, a także zwraca uwagę na wartość notatek i spostrzeżeń prowadzonych w trakcie botanizowania. Podkreśla, iż „botanika ma najlepszą podporę w praktycznych ćwiczeniach, w badaniu i zbieraniu roślin". Informuje, że puszki botaniczne już wychodzą z użycia, są niewygodne i stają się niemodne. Wzywa do umiaru podczas zbierania roślin: „Początkujący nie powinien prowadzić gospodarki rabunkowej, co się niestety wszędzie dzieje koło miast z licznymi szkołami średnimi. Tam młodzież, gdzie znajdzie jaką rzadką roślinę nie ogranicza się do starannego wykopania jednego egzemplarza, ale wyrywa wszystkie jakie tylko znajdzie. Ten sposób prowadzi szybko do zubożenia flory i wytępienia rzadkich gatunków. Botanik powinien znać „ochronę przyrody”, i nie łamać gałązek drzewa ochranianego ani zrywać takich roślin."

Podobnie jak jego poprzednicy zaleca zbierać nasiona i dołączać w osobnej kopertce do okazu zielnikowego. W przypadku roślin mięsistych, długo schnących, czerniejących, 
autor postuluje włożenie bibuły z rośliną do rury w piecu lub do piekarnika i ze względu na szybkie parowanie, częste (co godzinę) przekładanie rośliny.

Również w 1924 r. zostaje opublikowana obszerna praca zoologa Kazimierza Simma (1884-1954), pt. Muzeum przyrodnicze, wskazówki do sporzqdzania i konserwowania zbiorów przyrodniczych (SıMM 1924), wydana nakładem księgarni B. Kotuli w Cieszynie. Autor uważa botanizerkę za sprzęt zupełnie nieużyteczny. Podkreśla, iż rośliny szybko w niej więdną, a dodatkowo przeszkadza w czasie chodzenia i schylania się. Wszystkie używane narzędzia należy nosić w plecaku (karteczki papierowe, klucz do oznaczania roślin, igły preparacyjne, najlepiej rogowe lub kościane szczypczyki, skalpel oraz szarą bibułę). Zaleca oznaczać rośliny przed suszeniem. W celu uwidocznienia wnętrza kwiatu, powinno się usunąć kilka płatków lub działek kielicha, aby wszystkie szczegóły na suchym okazie były łatwo dostępne, a w przypadku kiedy korona jest rurkowa należy między płatki wkładać kawałki papieru. Najlepsze wyniki uzyskuje się susząc rośliny w drucianych siatkach, w warstwach o grubości do $10 \mathrm{~cm}$. Uświadamia również, jak sprawdzić czy okaz jest już dobrze zasuszony: „Suchy zupełnie okaz poznaje się po tym, że dotknięty górną stroną

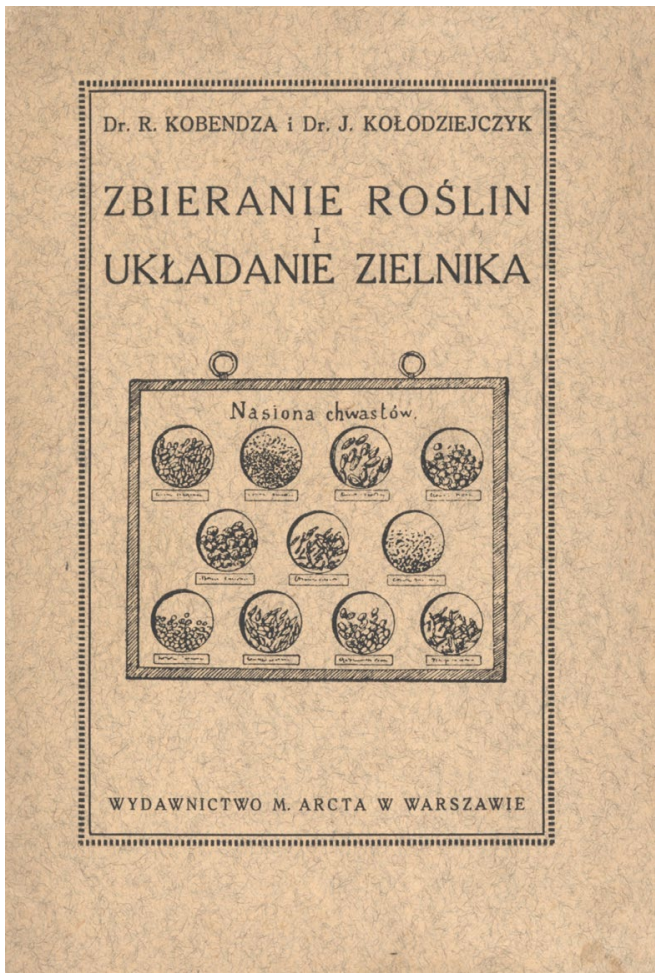

Ryc. 8. Wspólna praca Romana Kobendzy i Januarego Kołodziejczyka dotycząca metodyki wykonywania zielników (KoBENDZA \& KoŁODZIEJCZYK 1927)

Fig. 8. Joint work on methodology for preparation of herbaria, by Roman Kobendza and January Kołodziejczyk (KoBENDZA \& KoŁODZIEJCZYK 1927) ciepłej ręki lub końcem języka nie wywołuje wrażenia chłodu". Według Simma okazy powinny być przyklejane do arkuszy cieniutkimi paskami papieru, tylko na końcach, aby sama łodyga tkwiła dość luźno. Gatunki w teczkach rodzajowych radzi porządkować według ich następstwa w kluczu, którym posługiwano się do oznaczania. Teczki zielnikowe powinno się układać w pozycji leżącej, a dla zabezpieczania zbiorów przed owadami należy odkażać zbiory botaniczne dwusiarczkiem węgla w skrzyniach dezynfekcyjnych, układając arkusze $\mathrm{z}$ okazami możliwie luźno. Po odkażeniu trzeba zielnik dobrze przewietrzyć. W przypadku paproci, najlepiej zbierać dwa pokolenia, tj. gametofit i sporofit. Sporofit powinien być zbierany w postaci liści z zarodniami.

W 1927 r. opublikowana została wspólna praca dwóch botaników warszawskich: Romana Kobendzy (1886-1955) i Januarego Kołodziejczyka (1889-1949), pt. Zbieranie roślin, uktadanie zielnika, przewodnik do zbierania, suszenia, oznaczania roślin i uktadania zielnika (Ryc. 8), wydana przez wydawnictwo M. Arcta w Warszawie (KoBENDZA \& KoŁODZIEJCZYK 1927). Autorzy we wstępie informują, iż na prośbę wydawnictwa 
opracowali krótki przewodnik, który szczególnie polecają nauczycielom, uczniom szkół powszechnych i średnich, seminariów i początkujących amatorów. Autorzy podkreślają znaczenie odpowiedniego przygotowania do wycieczki, zaczynając od wygodnego obuwia, ubrań, poprzez przybory do botanizowania, a kończąc na żywności, przyborach do szycia oraz aparacie fotograficznym. Dalsza część dotyczy zbioru roślin w terenie. Autorzy opisują krótko poszczególne grupy roślin, sposoby ich zbioru, preparowania i suszenia. Kolejne wiadomości dotyczą oznaczania roślin, zawierają informacje o podstawowych kluczach, atlasach i florach przydatnych do pracy z różnymi grupami taksonomicznymi. Szczegółowo opisane jest układanie zielnika, cele jakim ma on służyć oraz różne sposoby dezynfekcji. W ostatnim rozdziale autorzy podkreślają wartość naukową dobrze wykonanego zielnika.

Bohdan Dyakowski (1864-1940), znany popularyzator wiedzy przyrodniczej w jednym z swych podręczników (DYAKOWSKI 1923) podkreśla, iż zbieranie roślin do zielników uczy dzieci obserwacji w przyrodzie, wymaga dokładności i staranności, ponadto niejako wymusza dłuższy pobyt na świeżym powietrzu: „rośliny których zbieranie i zasuszanie jest rzeczą niezmiernie łatwą nawet dla młodszych uczniów, nie jest połączone z zabijaniem, wymaga dokładności i porządku w odrobieniu, a więc posiada pod tym względem kształcące znaczenie".

W literaturze nie brak jednak odmiennych, krytycznych głosów dotyczących zbioru roślin do zielnika. I tak, Marian Sokołowski (1894-1939) wskazuje, że zielniki służą do masowego niszczenia okolicznej flory, zagrażają „zwłaszcza t.zw. rzadkim gatunkom, które uczniowie ze szczególnym zamiłowaniem starają się włączyć do swych zbiorów" (SoKоŁowski 1925). Jednakże w innym miejscu autor pisze „,nie można znów zaprzeczyć, że zielnik jest cennym środkiem pomocniczym w nauce botaniki, zwłaszcza jej części systematyczno opisowej." Niemniej, według autora, zielniki powinny zostać zastąpione systematycznymi wycieczkami terenowymi, na których nauczyciel zapoznawałby uczniów z budową, cechami charakterystycznymi, ekologią i rozmieszczeniem poszczególnych gatunków roślin. Co ciekawe, Sokołowski dopuszcza zbiór roślin w przypadku uczniów botanicznie uzdolnionych i zamiłowanych (SoKOŁOwSKI 1924). Zbieżne poglądy z Sokołowskim przedstawia Stanisław Bełżecki (1887-1945) (BEŁŻECKI 1927), który cytuje Sokołowskiego.

Zdecydowanie krytyczną uwagę na temat tworzenia zielników wyraził również Dezydery Szymkiewicz (1885-1948). Autor stwierdza iż „Rośliny martwe tylko w stanie suszonym nadają się do pokazów, ale nawet $\mathrm{w}$ tym wypadku wyglądają nieefektownie i z powodu ułożenia wszystkich części w jednej płaszczyźnie nie odtwarzają należycie żywych roślin” (SzYMKIEWICZ 1926). Na koniec apeluje do nauczycieli: „W szczególności nie należy wymagać od uczniów zbierania zielników. Zielniki uczniowskie nie mają żadnego znaczenia pedagogicznego, ani naukowego, a przy większej ilości szkół spowodują zupełne wytępienie ciekawych i ładniejszych roślin w naszym kraju, którego szata roślinna jest już w strzępach. Jest to barbarzyństwo, które powinno być bezwarunkowo zwalczane". Równie krytyczną opinię dotyczącą zbiorów zielnikowych wyraził E. Hassenpflug (?-?) w książce Obcowanie z przyrodq... (HASSENPFLUG 1928): „Zielników nie popierałbym, gdyż zawierają one trupy, które mają tylko znaczenie dla specjalistów systematyków", a „dla nauczania na podstawie biologicznej nie ma on jednak wartości, gdyż przedstawia tylko zniekształconą i płasko sprasowaną roślinę". 


\section{UWAGI KOŃCOWE}

Początkowo instrukcje dotyczące zbioru, suszenia oraz przechowywania zbiorów zasuszonych roślin miały charakter typowo naukowy i do takiego też celu służyły. Z czasem poszczególni autorzy korzystając z wiedzy poprzedników dodawali własne spostrzeżenia, doświadczenia i uwagi. W późniejszym czasie, w miarę wzrostu liczby wydawnictw pro-

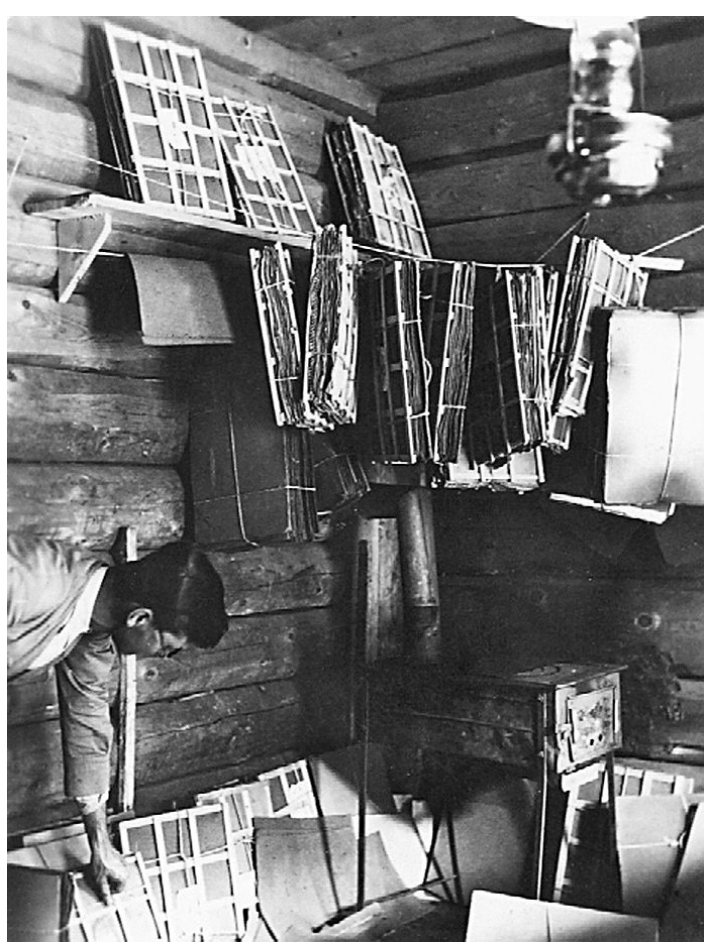

Ryc. 9. Profesor Bogumił Pawłowski podczas pracy z zielnikami

Fig. 9. Professor Bogumił Pawłowski during work with herbaria pagujących zbieranie roślin, zielniki były gromadzone przez liczne grono hobbystów. Rośliny często służyły celom kolekcjonerskim i były wykorzystywane w dokształcaniu amatorów botaników. Posiadanie pięknego, bogatego zielnika, podobnie jak w przypadku bogatej biblioteki, świadczyło o wykształceniu i pozycji jej posiadacza. Początkowo, czyli od początku XIX w. do początku XX w., autorzy zachęcali czytelników do zbioru roślin i sporządzania zielników, a w dalszym etapie ich wymiany. $\mathrm{W}$ tym czasie zostało opublikowanych wiele prac metodycznych. Tendencja ta jest widoczna do lat dwudziestych XX w., co było niewątpliwie związane $\mathrm{z}$ chęcią poznania rodzimej flory i wymiany informacji między przyrodnikami. Krytyczne głosy nawołujące do ograniczenia lub całkowitego zaprzestania herboryzacji pojawiły się w latach dwudziestych ubiegłego wieku, kiedy zaobserwowano zanikanie rzadszych gatunków roślin.

Zmieniające się trendy można dostrzec także w ekwipunku botanika zbierającego rośliny. Osobliwym i obecnie nieznanym sprzętem terenowym dawnych florystów, związanym ze zbiorem roślin, była metalowa puszka w kształcie walca, mająca z boku metalowe drzwiczki. Dzięki paskowi była przewieszana przez ramię, co umożliwiało pracę w terenie. W późniejszym czasie została nazwana przez polskich botaników „botanizerką” (DroBNIK 2007). Pierwsze zdawkowe wzmianki o niej podaje ŚLENDZIŃSKI (1874), w późniejszym czasie (wczesne lata XX w.) była wymieniana jako podstawowe narzędzie botanika. O jej popularności w tym okresie mogą świadczyć zamieszczane liczne ogłoszenia firm produkujących pomoce naukowe ${ }^{8}$, jak również opisy jej wykorzystania w licznych pracach dotyczących zbioru roślin do zielników. Jednym

\footnotetext{
8 Taką firmą było Towarzystwo Urządzeń Szkolnych i Pomocy Naukowych „Uranja”, które produkowało liczne przybory dla botaników, m.in. botanizerki.
} 
z krytyków używania botanizerki podczas zbierania roślin był Kazimierz SiMM (1924): „puszki botaniczne są zupełnie nieużyteczne z dwu względów: 1. Rośliny w nich transportowane rychło więdną, zwłaszcza w upalne dni i gniotą się tak, że nieraz przy obfitym zbiorze trzeba połowę wyrzucić po przyniesieniu do domu; 2. zawadzają okropnie w czasie chodzenia i schylania się, obijając się o nogi i boki nieopatrznego zbieracza, wierzącego szumnym reklamom. Już pierwszy wzgląd wystarczyć powinien, aby puszki zarzucić zupełnie". Trudno powiedzieć, czy ta opinia przyczyniła się do zaprzestania używania botanizerek, jednak faktem jest, iż po tym okresie były one coraz rzadziej wykorzystywane. Na początku XX w. popularność zyskały metalowe teczki (siatki), o których pierwszy raz wspomniała w swojej pracy Maria ARCT-GolCZEwSKA (1905). Z czasem stały się one podstawowym narzędziem pracy wielu pokoleń botaników. Swą popularność zyskały dzięki możliwości jednoczesnego wykorzystania ich do zbioru oraz suszenia roślin (Ryc. 9).

Podziękowania. Autor pragnie serdecznie podziękować za pomoc przy pisaniu niniejszej pracy Pani Profesor Alicji Zemanek i Panu Profesorowi Bogdanowi Zemankowi. Panu Profesorowi Tomaszowi Majewskiemu dziękuje za cenne uwagi oraz nieocenioną pomoc w dotarciu do materiałów źródłowych, które przyczyniły się do ostatecznego kształtu tekstu. Dziękuję również Panu doktorowi Bogusławowi Binkiewiczowi za przyjacielską dłoń i konsultacje.

\section{LITERATURA}

ANONIM 1816. Instrukcja do układania zapisów w przedmiocie botaniki. - Dziennik Wileński 4(7-12): 485-497.

ANONIM 1917. Wskazówki dla gromadzących zbiory krajoznawcze. s. 29. Oddział Lubelskiego Polskiego Towarzystwa Krajoznawczego, Lublin.

ANONIM 1919. Metodyka wycieczek krajoznawczych. s. 47-52. Polskie Towarzystwo Krajoznawcze, Warszawa.

ANONIM 1971. Zukerkandel Wilhelm (1851-1924). Encyklopedia wiedzy o książce. s. 2635-2636. Zakład Narodowy im. Ossolińskich, Wrocław - Warszawa - Kraków.

ARcTównA M. 1905. Wskazówki do zbierania, określania, zasuszania roślin i układania zielnika. Opracowała według podręczników d-ra K. G. Lutz’a i innych M. Arctówna. Książki dla wszystkich, nr 205. s. 92. M. Arct, Warszawa.

ARCTówNA M. 1905. Etykiety do zielnika zawierające 1230 nazw roślin ułożonych rodzinami. Książki dla wszystkich, nr 206. s. 128. M. Arct, Warszawa.

ARCTównA M. \& TRZebiński J. 1916. Wskazówki do zbierania roślin i układania zielnika, z krótkim opisem narządów roślin. Książki dla wszystkich, nr 205. s. 94, wyd. II. M. Arct, Warszawa.

BEŁŻECKI S. 1927. Udział nauczycieli w badaniach florystycznych na prowincji. - Życie szkolne, Włocławek 1: 1-71.

BEsser W. 1826. Przepisy do układania zielników. s. 14. Drukiem Jozefa Zawadzkiego, Wilno.

BŁońsKi F. 1889. Conspectus Muscorum Poloniae. Mchy Królestwa Polskiego część I. Mchy bocznozarodniowe. Bryinae pleurocarpae. Kilka słów o zbieraniu i określaniu mchów. - Pamiętnik Fizyograficzny 9: $133-138$.

BojKo P. 1905. Zielnik podręcznik dla zbierających rośliny. Biblioteka Powszechna, nr 524. s. 56. Nakładem i drukiem księgarni Wilhelma Zukerkandla, Złoczów

BoJKo P. 1923. Zielnik podręcznik dla zbierających rośliny. Biblioteka Powszechna, nr 524. s. 56, wyd. II. Nakładem i drukiem księgarni Wilhelma Zukerkandla, Złoczów. 
BRzozowsKi S. 1984. Dzieje Krajowej Szkoły Gospodarstwa Lasowego w latach 1874-1921. - Studia i Materiały z Dziejów Nauki Polskiej, Seria B, 32: 33-82. Państwowe Wydawnictwo Naukowe, Warszawa.

CienCiAŁA J. 1924. Zbieranie, zasuszanie i przechowywanie roślin. - Samouczek techniczny, wydawnictwo popularno-naukowe, nr 47. s. 31. Nakładem księgarni B. Kotuli, Cieszyn.

Czerwiakowski I. R. 1867. Sprawozdanie sekcji botanicznej. - Sprawozdanie Komisji Fizjograficznej c. k. Towarzystwa naukowego Krakowskiego 1: 25-27. Drukarnia C. K. Uniwersytetu Jagiellońskiego, Kraków.

CZERwiaKowsKi I. R. 1867. Instrukcja dla członków sekcji botanicznej Komisji fizjograficznej. - Sprawozdanie Komisji Fizjograficznej c. k. Towarzystwa naukowego Krakowskiego 1: 91-94. Drukarnia C. K. Uniwersytetu Jagiellońskiego, Kraków.

DAwID S. 1885. Herboryzacja czyli zbieranie, określanie i zasuszanie roślin. - Wszechświat 4(15): 225-229.

DAwID S. 1885. Herboryzacja czyli zbieranie, określanie i zasuszanie roślin (dokończenie). - Wszechświat 4(16): 245-250.

DrobNIK J. 2007. Zielnik i zielnikoznawstwo. s. 110. Wydawnictwo Naukowe PWN, Warszawa.

DYAKOwski B. 1923. Zarys metodyki niższego kursu nauki o przyrodzie. s. 106. wyd. II. Książnica Polska, Lwów - Warszawa.

DYвowski B. 1898. Zielnik flory polskiej, wydawany obecnie pod redakcją Prof. E. Wołoszczaka. - Kosmos 23(1-4): 643. Polskie Towarzystwo Przyrodników im. Kopernika, Lwów.

Dyвowski W. 1899. Skorowidz do zielnika flory polskiej. - Kosmos 24: 100-112. Polskie Towarzystwo Przyrodników im. Kopernika, Lwów.

DYвowski W. 1899. Skorowidz do zielnika flory polskiej (dokończenie). Spis roślin do zielnika flory polskiej ułożony abecadłowo. - Kosmos 24: 350-386. Polskie Towarzystwo Przyrodników im. Kopernika, Lwów.

FiLIPOwICZ K. 1882. Rośliny Skrytokwiatowe (Cryptogamae.), opisanie ich budowy, tudzież sposobów zbierania, preparowania i badania. - Wszechświat 1(2): 17-20; 1(4): Tab. I, Tab. II; 1(5): 67-71; 1(6): 90-94; 1(13): 196-201; 1(14): 215-219; 1(32): Tab. III, Tab. IV; 1(33): 513-517; 1(34): 532-536; 1(35): 553-558; 1(36): 571-575; 1(37): 583-587. Warszawa.

Filipowicz K. 1883. Rośliny Skrytokwiatowe (Cryptogamae.), opisanie ich budowy, tudzież sposobów zbierania, preparowania i badania. - Wszechświat 2(19): Tab. V, Tab. VI ; 2(20): 305-309; 2(21): 328-334.

FiLIPOwICZ K. 1884. Rośliny Skrytokwiatowe (Cryptogamae.), opisanie ich budowy, tudzież sposobów zbierania, preparowania i badania. Odbitka z Wszechświata. s. 233, I-XXXVIII, I-VI Tablic. Druk J. Bergera, Warszawa.

GręBECKA W. 1988. Badania szaty roślinnej prowadzone w ośrodku Wileńskim i Krzemienieckim (1781-1840). - W: J. BABICZ \& W. GRĘBECKA (red.), Wkład wileńskiego ośrodka naukowego w przyrodnicze poznanie kraju (1781-1842), s. 115-225. Wrocław.

GręBECKA W. 1992. Historia naturalna w Liceum Krzemienieckim (1805-1832). - Analecta. Studia i Materiały z Dziejów Nauki 1(1): 139-189.

GRĘBECKA W. 1993. Ankieta fizjograficzna jako forma organizacji badań. - Kwartalnik Historii Nauki i Techniki 1: 93-105.

GRĘBECKA W. 2004. Besser Willibald (1784-1842). - W: S. MAKOwSKI (red.), Krzemieniec Ateny Juliusza Słowackiego, s. 404-411. Warszawa.

Hassenpflug E. 1928. Obcowanie z przyrodą. Przewodnik metodyczny dla nauczycieli przyrody. s. 519. Książnica - Atlas, Warszawa. 
HRYNIEWIECKI B. 1922. Zielnik i muzeum botaniczne, wskazówki praktyczne: jak zbierać, preparować, konserwować, oznaczać rośliny i układać zbiory botaniczne. s. 209. Gebethner i Wolff. Warszawa - Kraków - Lublin- Łódź - Poznań - Wilno - Zakopane.

HRYNIEWIECKI B. 1923. Instytut wymiany zielników przy Zakładzie system. i geografii roślin Uniwersytetu Warszawskiego. - Przyroda i Technika 2(7): 504-506. Książnica Polska Towarzystwa Szkół Wyższych, Lwów - Warszawa.

HrYNIEWIECKI B. 1926. Poradnik dla Samouków. Wskazówki metodyczne dla studiujących pod redakcją Stanisława Michalskiego, wydanie nowe, tom VI, Botanika, cz. 1. s. 712. Wydawnictwo Kasy im. Mianowskiego, Warszawa.

KIELAK A. 2006. Zielnik roślin nadniemeńskich Elizy Orzeszkowej. s. 79. SZ „Towarzystwo Kultury Polskiej Ziemi Lidzkiej”, Warszawa - Lida.

KLUK K. 1785. Botanika dla szkół narodowych Pierwszy raz wydana. s. 238. Drukarnia Nadworna J. K. Mci i P. Kom: E. N., Warszawa.

KobendzA R. \& KoŁodZIEJCZYK J. 1927. Zbieranie roślin i układanie zielnika. s. 38. Wydawnictwo M. Arct, Warszawa.

KöHLER P. 2015. Komisja Fizjograficzna i jej rola w rozwoju badań botanicznych w Polsce. - Wiadomości Botaniczne 59(1-2): 1-19.

Łoś W. 1888. Zbieranie roślin i urządzanie zielnika. s.19. PISA tipografia T. NISTRI e C. Pisa.

Łoś W. 1890. Przewodnik dla urządzających zbiory botaniczne i entomologiczne. Wydanie drugie. s. 46. Księgarnia Edwarda Kolińskiego, Warszawa.

MAJewSKi T. 2005. Botanika w warszawskich czasopismach „Pamiętnik Fizjograficzny” i „Wszechświat”. - Analecta. Studia i Materiały z Dziejów Nauki 14(1-2): 147-165.

MĄDALSKI J. 1951. Zbieranie i konserwowanie roślin do celów naukowych (z opisem nowej metody suszenia). s. 52. Państwowe Wydawnictwo Naukowe, Wrocław.

MĄDALSKI J. 1955. Jak należy zbierać i konserwować rośliny do celów naukowych (z 17 rysunkami). s. 87. Państwowe Wydawnictwo Naukowe, Warszawa.

MUSZYŃSKI J. K. 1908. Jak należy zbierać rośliny i układać zielniki. Opracowanie według podręcznika prof. S. Rostowcowa. Tow. Farmacja. s. 39. Warszawa.

MUSZYŃSKI J. K. 1928. Jak należy zbierać rośliny i układać zielniki. Wilno.

RACIBORSKI M. 1911. Wskazówki dla zakładających muzea przyrodniczo-krajoznawcze. - Kosmos 36(3-6): 625-635. Polskie Towarzystwo Przyrodników im Kopernika. Lwów.

Rehman A. \& WoŁoszczak E. 1891. Zaproszenie do współudziału w wydawnictwie „Zielnika Flory polskiej”. - Kosmos 16(11-12): 413-416. Polskie Towarzystwo Przyrodników im. Kopernika. Lwów.

RosTAFIŃSKI J. 1886. Botanika szkolna dla klas niższych, z dodatkiem bezpłatnym, zawierającym klucze do oznaczania pospolitych roślin. s. 120, 52. Nakładem Towarzystwa Nauczycieli Szkół Wyższych. Drukarnia „Czasu” Fr. Kulczyckiego i Spółki, Kraków.

RosTAFIŃSKI J. 1901. Przewodnik do oznaczania krajowych roślin Nasiennych. Przez [...] [Wydanie drugie, pomnożone] s. 109. Nakładem autora, Kraków.

RosTAFIŃSKI J. 1906. Przewodnik do oznaczania pospolitszych roślin. [Wydanie trzecie]. s. 140. Nakładem autora, Kraków.

RosTAFIŃSKI J. 1911. Przewodnik do oznaczania 1000 roślin dzikich i hodowanych. [Wydanie czwarte]. s. 152. Nakładem autora, Kraków.

Simm K. 1924. Muzeum przyrodnicze, wskazówki do sporządzania i konserwowania zbiorów przyrodniczych. s. 157. Nakładem księgarni B. Kotuli, Cieszyn. 
SoKoŁOWSKi M. 1924. Ochrona przyrody jako przedmiot nauczania w szkołach powszechnych i średnich. - Przyrodnik 1(10): 440-443. Wydawnictwo B. Kotuli, Cieszyn.

SoKoŁowski M. 1925. O wprowadzeniu ochrony przyrody do nauczania szkolnego. - Ochrona Przyrody, Organ Państwowej Komisji Ochrony Przyrody. 5: 8-9. Państwowa Komisja Ochrony Przyrody, Kraków.

SzYMKIEWICZ D. 1926. Uwagi o nauczaniu botaniki w szkołach średnich. Odbitka z miesięcznika Szkoła i Nauczyciel. 1: 1-11. Łódź.

SZYSZYŁOWICZ I. 1890. Nowy sposób konserwowania kwiatów. - Wszechświat 9(7): 105-106.

ŚLENDZIŃSKI A. J. 1874. Poradnik dla urządzających zbiory przyrodnicze. s. 80-96. Drukarnia W. Korneckiego, Kraków.

TRZEBIŃSKI J. 1909. Metodyka Botaniki. - Prace metodyczne w zakresie wykształcenia średniego, zebrane staraniem Wacława Jezierskiego, nr 3c. s. 1-51. Polski Związek Nauczycielski, Warszawa.

TRZEBIŃSKI J. 1917. Jak zbierać i oznaczać rośliny. s. 41. Wydawnictwo M. Arcta, Warszawa.

\section{SUMMARY}

Early methodological works on collecting, drying and storing plants were for a scientific readership (Fig. 3). Over time, the authors of manuals used the knowledge of their predecessors, adding their own insights, experience and comments. Later, as the number of publications promoting plant collection increased, herbaria were collected by a large group of hobbyists, often just for the sake of collecting. Besides information on methods of handling of harvested plant, information about prices and places the necessary equipment was often included, together with a list of literature helping to identify specimens (Fig. 7). A beautiful, rich herbarium, like a rich library, attested to the education and social position of its owner. From the beginning of the nineteenth century, the authors of numerous manuals encouraged readers to collect plants and make herbaria. This trend persisted noticed until the 1920s, when the number of specimens of rare species began to decline as a result of overcollection. At that time, criticism appeared in print, calling for the reduction or complete cessation of plant collection.

Wptynęto: 14.02.2020 r.; przyjęto do druku: 05.06.2020 r. 